\title{
Battle Royale: Innate Recognition of Poxviruses and Viral Immune Evasion
}

\author{
Huibin Yu, Ryan C. Bruneau, Greg Brennan (D) and Stefan Rothenburg *(D) \\ Department of Medical Microbiology and Immunology, School of Medicine, University of California, \\ Davis, CA 95618, USA; glbyu@ucdavis.edu (H.Y.); rcbruneau@ucdavis.edu (R.C.B.); \\ gbrennan@ucdavis.edu (G.B.) \\ * Correspondence: rothenburg@ucdavis.edu
}

Citation: Yu, H.; Bruneau, R.C.; Brennan, G.; Rothenburg, S. Battle Royale: Innate Recognition of Poxviruses and Viral Immune Evasion. Biomedicines 2021, 9, 765. https://doi.org/10.3390/ biomedicines 9070765

Academic Editor: Michael H. Lehmann

Received: 21 May 2021

Accepted: 26 June 2021

Published: 1 July 2021

Publisher's Note: MDPI stays neutral with regard to jurisdictional claims in published maps and institutional affiliations.

Copyright: (C) 2021 by the authors. Licensee MDPI, Basel, Switzerland. This article is an open access article distributed under the terms and conditions of the Creative Commons Attribution (CC BY) license (https:// creativecommons.org/licenses/by/ $4.0 /)$.

\begin{abstract}
Host pattern recognition receptors (PRRs) sense pathogen-associated molecular patterns (PAMPs), which are molecular signatures shared by different pathogens. Recognition of PAMPs by PRRs initiate innate immune responses via diverse signaling pathways. Over recent decades, advances in our knowledge of innate immune sensing have enhanced our understanding of the host immune response to poxviruses. Multiple PRR families have been implicated in poxvirus detection, mediating the initiation of signaling cascades, activation of transcription factors, and, ultimately, the expression of antiviral effectors. To counteract the host immune defense, poxviruses have evolved a variety of immunomodulators that have diverse strategies to disrupt or circumvent host antiviral responses triggered by PRRs. These interactions influence the outcomes of poxvirus infections. This review focuses on our current knowledge of the roles of PRRs in the recognition of poxviruses, their elicited antiviral effector functions, and how poxviral immunomodulators antagonize PRR-mediated host immune responses.
\end{abstract}

Keywords: poxviruses; vaccinia virus; pattern recognition receptors; PKR; RNase L; ZBP1; cGASSTING; Toll-like receptors; inflammasome

\section{Introduction}

Members of the family Poxviridae can infect a diverse range of vertebrates and invertebrates, although some poxviruses have narrow host ranges and others have very broad host ranges [1]. Poxvirus infections have posed serious threats to both humans and animals worldwide [2]. Poxviridae is a large family of DNA viruses comprised of two subfamilies: Chordopoxvirinae and Entomopoxvirinae. There are currently 18 recognized genera of Chordopoxvirinae, which infect vertebrates, and 4 genera of Entomopoxvirinae, which infect invertebrates [1]. Poxviruses possess a single, linear double-stranded DNA (dsDNA) genome, which ranges in size from 127 to $456 \mathrm{~kb}$ and encodes several hundred gene products. Unlike most other DNA viruses, poxviruses replicate exclusively within the cytoplasm of permissive cells [3].

One of the best known poxviruses is variola virus (VARV), a member of the orthopoxvirus genus. VARV is the causative agent of human smallpox, which was one of the most devastating human diseases in history [4]. Despite the success of global smallpox eradication through a vaccination campaign led by the World Health Organization, other pathogenic poxviruses, such as monkeypox virus, cowpox viruses (CPXV), camelpox virus, tanapox virus, and capripoxviruses remain threats to human and animal health $[1,2,5,6]$. The most intensively studied poxviruses, such as vaccinia virus (VACV) and myxoma virus (MYXV), have proven to be excellent research models to study host innate recognition and virus-host protein interactions and have provided important insights into the fields of virology and immunology [7,8]. In turn, these fundamental insights have direct translational applications to improve the development of safer and more effective attenuated viral vectors for vaccines, cancer therapeutics, and other treatment modalities [9]. For example, 
in VACV inactivation of either IL-1 $\beta$-binding protein or IL-18-binding protein, encoded by B15R and C12L, respectively, enhanced $\mathrm{CD} 8^{+} \mathrm{T}$ cell memory responses after immunization and improved the protection against virulent VACV WR challenge [10,11]. In addition, VACV has the genomic capacity to incorporate $>25 \mathrm{~kb}$ of foreign DNA without noticeable impacts on viral replication. This capacity has been employed to genetically engineer VACV chimeras carrying multiple heterologous genes, as both polyvalent vaccines and treatment of various genetic diseases [12-15]. Multiple poxviruses are being investigated for use in oncolytic virotherapy. Myxoma virus (MYXV) is one such preclinical candidate oncolytic virus, and recombinant MYXV lacking various viral death modulator genes, such as M-T5 [16], M11 [17], M13 [18], and Serp2 [19], have enhanced anti-tumor activity that appears to be mediated through viral induction of programmed cell death rather than through viral replication (reviewed in [20]).

The recognition of viral pathogens and the host defense against them are provided by the innate and adaptive immune systems. The adaptive immune system is broadly comprised of antigen-specific $\mathrm{CD} 8^{+} \mathrm{T}$ cells, $\mathrm{CD} 4^{+}$helper $\mathrm{T}$ cells, and $\mathrm{B}$ cell antibody responses for specific, anamnestic protection against distinct pathogens [21-23]. Prior to the initiation of the adaptive immune response, pathogen-associated molecular patterns (PAMPs) derived from poxviruses, such as DNA and RNA, as well as envelope or core proteins, can be sensed by a diverse set of pattern recognition receptors (PRRs) to initiate the faster but less specific innate immune responses [24-31]. The innate immune response provides the first line of host defense and includes antiviral proteins that can lead to the direct elimination of viruses or induce the expression of type I interferons (IFNs), proinflammatory cytokines, chemokines, and other antiviral proteins [32,33]. These effector molecules mediate direct antiviral effects or orchestrate the adaptive immune response to contain poxvirus infections at various stages. In particular, type I IFNs, the hallmark effector of antiviral responses, are essential to initiate innate immunity and also to mediate the subsequent development of adaptive immunity against invading poxviruses [34]. In addition, type I IFNs upregulate the expression of hundreds of IFN-stimulated genes (ISGs) that directly influence protein synthesis, cell growth, and survival to establish an antiviral state $[35,36]$. Furthermore, multiple cytokines, such as interleukin-6 (IL-6), IL-12, and tumor necrosis factor-alpha (TNF $\alpha)$, can be induced during poxvirus infections which then act systemically to induce immune responses [37,38].

Over recent decades, substantial progress has been made in defining the roles of PRRs and the subsequent signaling pathways that are involved in the sensing of and response to poxviruses. IFN expression is transcriptionally regulated through activation of IFN regulatory factor (IRF) family members or coordinated activation of IRFs and nuclear factor kappa B (NF-kB) [39]. The stimulation of proinflammatory genes depends on activation of the transcription factors NF- $\mathrm{kB}$ and activator protein 1 (AP1) [40]. Despite the diversity of PRR ligands, many PRR-regulated signaling pathways share common downstream molecules, such as myeloid differentiation primary response gene 88 (MyD88) and Toll/interleukin-1 receptor domain-containing adapter-inducing interferon- $\beta$ (TRIF). Thus, there is substantial crosstalk and overlap between the signaling cascades stimulated by different PRRs, which lead to IFN activation and also drive the production of other cytokines [41-43].

A broad spectrum of PRRs has been implicated in poxvirus recognition, including RNA sensors, cytosolic DNA sensors, multiple Toll-like receptors (TLRs), and components of the inflammasome. In order to establish successful infections in the face of this multi-pronged immune response, poxviruses evade host antiviral responses by expressing a variety of viral proteins. Those viral proteins interact with and antagonize the key components of these intracellular signal transduction pathways. In this review, we discuss our current knowledge concerning how innate receptors or sensors detect poxviruses and how PRRmediated recognition translates into effective antiviral immune responses. Following each sensor, we present mechanisms employed by poxviruses to thwart PAMP recognition by the host and how poxviruses manipulate PRR-mediated signaling pathways to their benefit. 


\section{Double-Stranded RNA-Activated Sensors and Poxvirus Antagonists}

The lifecycle of most virus families generates double-stranded RNA (dsRNA). In Poxviridae, dsRNA is the result of overlapping transcripts, which form duplexes, primarily at intermediate and late time points in the viral replication cycle [44-46]. Due to the ubiquity of this PAMP, it is perhaps not surprising that the first PRRs to be described were the dsRNA-activated molecules PKR and OAS/RNase L [35,47-51]. Since these initial discoveries, other broadly acting antiviral dsRNA sensors have been identified, and we have developed a better understanding of the plethora of mechanisms that viruses employ to evade these host proteins (Figure 1). In this section, we describe the mechanisms that these host proteins use to sense dsRNA, the antiviral pathways that they initiate, and the strategies poxviruses employ to inhibit them.

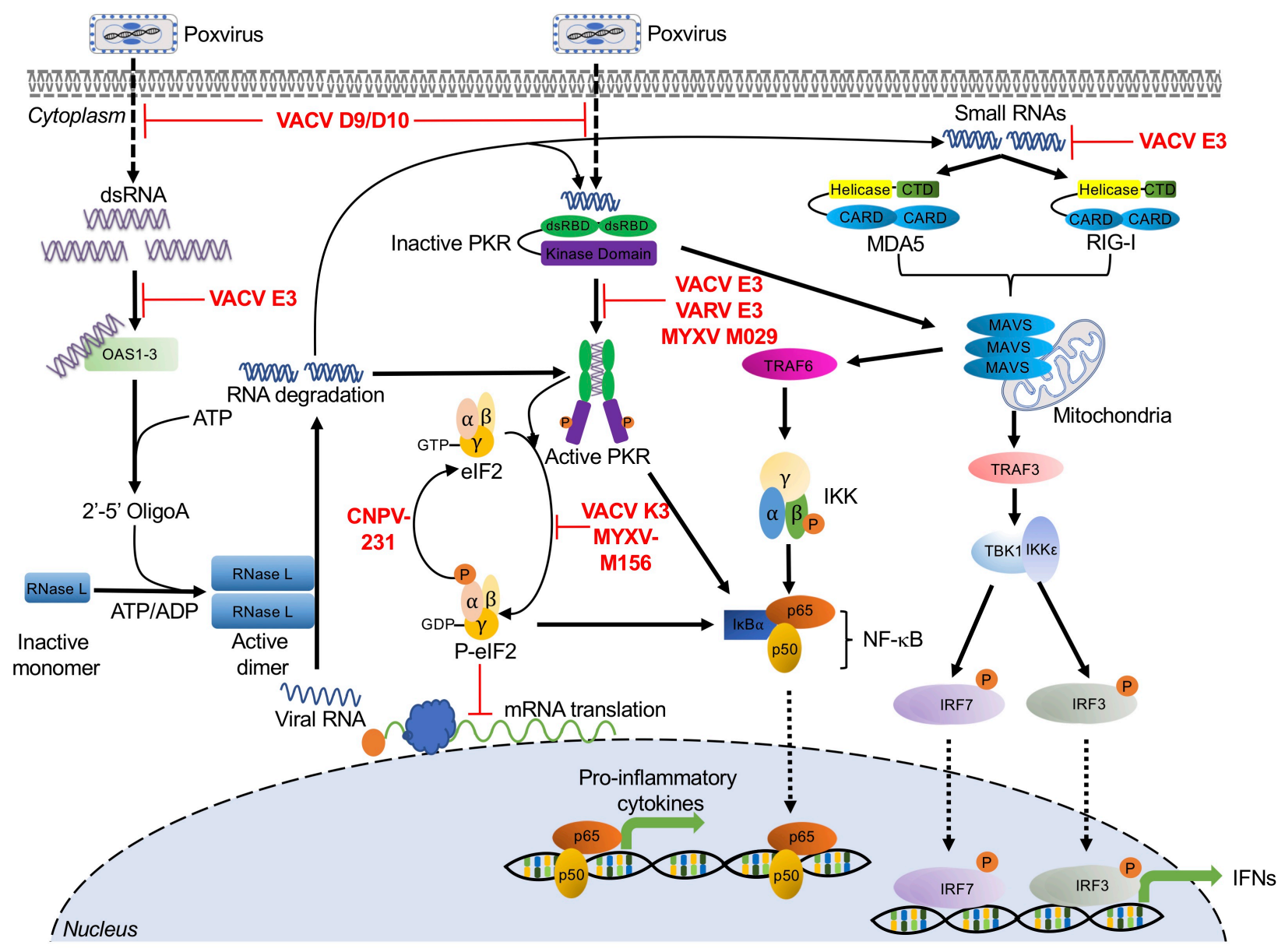

Figure 1. dsRNA sensor-mediated signaling pathways and poxvirus antagonists. The figure presents host sensors (black text) involved in recognizing dsRNA species from poxviral infections, and the elicited signaling cascades by these sensors, which are indicated by black arrows. Poxvirus-encoded immunomodulatory proteins that inhibit activation of these host pathways are indicated in red text and their effects on pathways are indicated by red lines. See main text for corresponding details and the underlying molecular mechanisms. Abbreviations used in this figure include ADP: adenosine diphosphate; ATP: adenosine triphosphate; CARD: caspase activation and recruitment domains; CNPV: canarypox virus; CTD: carboxyterminal domain; dsRBD: dsRNA binding domain; dsRNA: double-stranded RNA; eIF2: eukaryotic translation initiation factor 2; GDP: guanosine diphosphate; GTP: guanosine-5'-triphosphate; IKK $\alpha$ : IкB $\alpha$ kinase $\alpha$; IKK $\beta$ : IкB $\alpha$ kinase $\beta$;

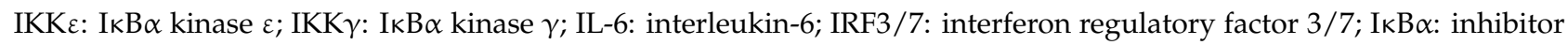
$\kappa \mathrm{B} \alpha$; MAVS: mitochondrial antiviral-signaling protein; MDA5: melanoma differentiation-associated protein 5; MYXV: myxoma virus; NF-кB: nuclear factor kappa B; OAS: 2' -5'-oligoadenylate synthetases; p65/p50: NF- $\mathrm{B}$ heterodimer p50/p65 subunit; PKR: protein kinase R; RIG-I: retinoic acid-inducible gene I; RNase L: ribonuclease L; TBK1: TRAF family memberassociated NF- $\mathrm{KB}$ activator (TANK)-binding kinase 1; TNF $\alpha$ : tumor necrosis factor-alpha; TRAF3/6: tumor necrosis factor receptor-associated factor 3/6; VACV: vaccinia virus; VARV: variola virus. 


\subsection{Protein Kinase $R$}

Protein kinase $\mathrm{R}$ (PKR) was first discovered as an IFN-stimulated, dsRNA-dependent protein kinase $[35,47,48]$. PKR is comprised of two N-terminal dsRNA binding domains (dsRBDs) and a C-terminal catalytic kinase domain [52]. These functional domains allow PKR to serve as both an intracellular sensor for double-stranded RNA (dsRNA) and an effector serine/threonine protein kinase. PKR is expressed in most cell types as an inactive monomer at intermediate levels. PKR recognizes dsRNA via its dsRBDs, and this binding event leads to PKR dimerization and autophosphorylation [53,54]. Activated PKR phosphorylates the alpha subunit of the eukaryotic translation initiation factor 2 (eIF2), which forms the ternary complex together with initiator methionyl-tRNA and GTP. Concomitant with translation initiation, GTP is hydrolyzed to GDP, which must subsequently be exchanged with GTP by the guanine nucleotide exchange factor eIF2B (reviewed in [55]). However, phosphorylated eIF2 $\alpha$ has increased binding affinity between eIF2 and eIF2B. This increased affinity effectively turns eIF2 $\alpha$ into an inhibitor of eIF2B, thus impairing the generation of active GTP-bound eIF2 and inhibiting the initiation of capdependent translation, ultimately leading to cell death and inhibition of viral replication (Figure 1) [56-59].

In addition to its canonical function as an eIF2 $\alpha$ kinase, PKR has also been implicated in different stress-induced signaling pathways including IFN responses and NF$\kappa B$-dependent inflammatory responses [60-62]. It has been reported that PKR activation decreases the protein levels of $\mathrm{I} \kappa \mathrm{B} \alpha$, the NF- $\mathrm{kB}$ inhibitor, thus activating this pathway. The molecular mechanism underlying this activation appears to rely on the kinase activity of PKR which has been shown to be essential for NF- $\mathrm{kB}$ activation [61,63]. Additionally, during infection with VV $\triangle E 3 \mathrm{~L}$, a VACV lacking the PKR antagonist protein E3, PKR was shown to regulate melanoma differentiation-associated protein 5 (MDA5)-mediated IFN $\beta$ production through a mechanism that does not require eIF $2 \alpha$ phosphorylation. Interestingly, PKR activation also upregulated IFN induction by MAVS (mitochondrial antiviral-signaling protein) in an MDA5-independent manner [64]. Similarly, in human and murine cells infected with a modified vaccinia virus Ankara (MVA) strain engineered to produce more dsRNA, the expression of IFN $\beta$ increased. Furthermore, mice infected with this MVA strain showed increased expression of IFN $\alpha$, IFN $\gamma$, and other cytokines, which were enhanced in a PKR-dependent manner [27].

\section{Poxvirus Evasion of PKR}

Poxviruses encode diverse PKR antagonists that either directly or indirectly inhibit the PKR pathway. In VACV, these proteins are encoded by E3L, K3L, D9R, and D10R. In addition, avipoxviruses possess homologs of cellular protein phosphatase 1 (PP1) targeting growth arrest and DNA damage-inducible protein 34 (GADD34, PPP1R15A) and constitutive repressor of eIF $2 \alpha$ phosphorylation (CREP, PPP1R15B), which promote the dephosphorylation of eIF2 $\alpha$ (Figure 1) [65].

E3 was initially characterized as a dsRNA-binding protein responsible for IFN resistance. This phenotype was dependent on the C-terminal domain of E3, which contains a dsRBD [66]. E3 can bind dsRNA via this dsRBD to prevent PKR dimerization and activation $[67,68]$. In human-derived HeLa cells, an E3L-deleted VACV displayed a replication defect [69]. Moreover, this E3L-deleted VACV was able to replicate in PKR-deficient HeLa cells as efficiently as wild type VACV, which demonstrated that PKR was the major target of E3 in these cells [70]. However, VACV $\triangle E 3 \mathrm{~L}$ replication in Syrian hamster-derived BHK cells was not affected, suggesting that, as with most other host range genes, there is a species-specific component to E3 activity. Additionally, E3 orthologs from myxoma virus and swinepox virus were shown to inhibit PKR activity and impair the induction of IFN $\beta$ and proinflammatory cytokines, such as TNF $\alpha$ and IL-6, during viral infection [68,71]. Interestingly, E3L orthologs from myxoma virus and swinepox, but not from sheeppox virus, were able to rescue virus replication when expressed by a VACV $\triangle \mathrm{E} 3 \mathrm{~L}$ chimera. These 
PKR-inhibitory activities correlated with PKR inhibition in vitro studies as well, further supporting the hypothesis that there are ortholog-specific differences in E3 activity [68,72].

VACV K3 and its orthologs in other poxviruses are structural mimics of eIF $2 \alpha$. They act as pseudosubstrate inhibitors and compete with eIF $2 \alpha$ to bind PKR, thus preventing eIF2 $\alpha$ phosphorylation and allowing protein synthesis to continue [73-75]. As with E3L, K3L was also identified as a VACV host range gene when a K3L-deleted VACV was able to replicate in HeLa cells but not in BHK cells [69]. Further evidence for this host range function is provided by the observation that $\mathrm{K} 3$ orthologs from multiple poxvirus genera exhibited both virus- and host-specific inhibition of PKR in both reporter- and infection-based assays [72,76-79].

VACV encodes two decapping enzymes D9 and D10, which share approximately 25\% amino acid sequence identity [80,81]. D9 and D10 are expressed either early or late in infection, respectively. They cleave $\mathrm{m}^{7} \mathrm{GDP}$ from capped RNA substrates through nudix hydrolase motifs. This decapping activity reduced mRNA stability and prevented dsRNA accumulation, thereby indirectly preventing PKR activation. Inactivation of D9 and D10 catalytic activities increased PKR-induced eIF $2 \alpha$ phosphorylation and enhanced PKR- and OAS/RNase L-mediated antiviral responses during VACV infection [81-84].

E3 and K3 orthologs evolved in mammalian poxviruses after the split from avipoxviruses [85]. In order to inhibit PKR, avipoxviruses evolved inhibitors that act later in the PKR pathway, facilitating the dephosphorylation of eIF2 $\alpha$. These proteins are homologous to the PP1 adaptor proteins GADD34 and CREP. In a yeast-based system, the canarypox virus protein 231 reversed the cytotoxic effects of ectopically expressed human PKR and reduced the level of PKR-induced eIF2 $\alpha$ phosphorylation [65]. The roles of avipoxviral GADD34 homologs in poxvirus infection still need to be elucidated.

\subsection{2'-5'-Oligoadenylate Synthetase (OAS)/RNase L}

The $2^{\prime}-5^{\prime}$-oligoadenylate synthetase (OAS)/RNase L-mediated antiviral pathway was discovered as one of the first interferon-induced systems in response to diverse viral infections [36]. The OAS family includes OAS1, OAS2, and OAS3 and their expression can be upregulated by type I and type III IFNs [86]. These molecules detect accumulated dsRNA species from diverse sources, which are usually viral but may sometimes have cellular origins $[87,88]$. Upon binding dsRNA, enzymatically active OAS1, OAS2, and OAS3 use ATP to synthesize linear $2^{\prime}-5^{\prime}$-linked second messenger molecules called $2^{\prime}-5^{\prime}$-oligoadenylates (2-5As) [36,89]. 2-5As, in turn, bind and activate latent RNase L monomers in the cytoplasm, inducing RNase L dimerization and activation. Activated RNase L suppresses viral replication by cleaving viral and cellular RNAs, limiting mRNA translation and promoting apoptosis (Figure 1). The resulting RNA cleavage products can be recognized by other RNA sensors, such as PKR, retinoic acid-inducible gene I (RIG-I), and MDA5 (Figure 1). Thus, RNase $\mathrm{L}$ acts to both inhibit viral replication itself and amplify the response of other innate immune proteins [90-93]. For example, RNase L activation has been shown to amplify IRF3-dependent IFN production by inducing the formation of antiviral stress granules, for which PKR and RIG-I are essential mediators [93].

Multiple studies have demonstrated that the antiviral activity of OAS/RNase L limits poxvirus infections. In response to VACV infection, RNase L knockout (KO) C57BL/6 mice were more susceptible to viral infection than wild type mice, indicating that RNase L plays an antiviral role in vivo [28]. Recombinant VACV expressing OAS or RNase L showed impaired viral replication relative to wild type VACV. This replication defect was accompanied by increased rRNA degradation and inhibition of virus protein synthesis [94]. In A549 cells, OAS3, but not OAS1 or OAS2, played the dominant role in RNase L activation and subsequent antiviral effects in response to VACV infection [89].

\section{Poxvirus Evasion of OAS/RNase L}

VACV E3 has been shown to inhibit the activation of the OAS/RNase L system [95]. Compared to MVA infection, HeLa cells infected with MVA- $\Delta$ E3L inhibited viral replica- 
tion at multiple steps including viral late transcription, late mRNA translation, and viral DNA replication. These replication blocks were associated with activation of OAS/RNase L, rRNA degradation, and upregulation of host transcripts, such as IL-6 [96]. Furthermore, VACV $\triangle E 3 L$ replicated approximately 20-fold higher in RNase $L^{\mathrm{KO}}$ MEF cells than in cells with intact RNase L, suggesting that E3 is involved in suppression of the OAS/RNase L system [97]. As described above, the VACV decapping enzymes D9 and D10 reduce dsRNA accumulation and thus also inhibit OAS/RNase L-mediated antiviral responses [81,83,98]. In A549 cells, knocking out both RNase L and PKR was necessary to allow replication of VACV $\triangle E 3 \mathrm{~L}$, whereas in HAP1 cells, PKR knockout alone was sufficient to allow VACV $\triangle E 3 L$ replication. These data highlight the cell type-specific activities of the OAS/RNase L pathway [99].

\subsection{RIG-I and MDA5}

Retinoic acid-inducible gene I (RIG-I) and melanoma differentiation-associated protein 5 (MDA5) are intracellular pathogen sensors and type I IFN inducers, which belong to the RIG-I-like receptors (RLRs) family [100,101]. RIG-I and MDA5 are localized in the cytosol of most cell types, where they recognize dsRNA derived from a variety of viral infections [64,102-108]. Both RIG-I and MDA5 contain a carboxy-terminal domain (CTD), two central helicase domains (Hel1 and Hel2), and two N-terminal caspase activation and recruitment domains (CARDs) [109]. Despite these similarities, RIG-I and MDA5 show different RNA binding preferences. RIG-I primarily senses and recognizes short RNA ligands containing $5^{\prime}$ triphosphate groups, while MDA5 mainly recognizes long dsRNA and replication intermediates [110-113]. Once activated, RIG-I and MDA5 both initiate signaling cascades through the adaptor protein MAVS. MAVS forms a multilayered complex to mediate downstream signal transduction, inducing type I interferons (IFNs) through IRF3 and IRF7 phosphorylation, and activating NF- $\mathrm{kB}$ through the tumor necrosis factor receptor (TNFR)-associated factor 6 (TRAF6)-mediated signal cascade (Figure 1) [112,114,115].

During poxvirus infections, RIG-I has been shown to play an essential role in sensing MYXV and triggering the induction of $\mathrm{TNF} \alpha$ and type I IFN in primary human macrophages in an IRF3- and IRF7-dependent manner [107]. Furthermore, in the presence of VACV DNA, RNA polymerase III exerts its antiviral effect by generating $5^{\prime}$ ppp RNA, which acts as a RIG-I substrate [106]. Additionally, VACV late RNA transcripts can be sensed by either RIG-I or MDA5 in a cell type-specific manner, triggering IFN $\beta$ gene transcription [116]. However, during MVA infection, MDA-5, but not RIG-I, was essential for the induction of IFN $\beta$ mRNA responses in THP-1 cells [29]. Although this activation specifically by late transcripts is intriguing, it remains unclear which poxviral RNA structures or motifs activate RIG-I and/or MDA5.

\section{Poxvirus Evasion of RIG-I and MDA5}

When infected with VACV $\triangle E 3 L$, mouse primary keratinocytes produced IFN $\beta$, IL6, and other cytokines in a MAVS- and IRF-3-dependent manner. MAVS and IRF3 are essential components of the RIG-I and MDA5 pathway. Production of these cytokines was completely prevented by infection with wild type VACV, or by VACV expressing only the E3 dsRNA binding domain [108]. Similarly, a second mechanism of E3 inhibition of RIG-I has been proposed that is mediated by inhibiting RIG-I recognition of RNA generated by RNA polymerase III [117].

\section{Dual RNA/DNA Sensor}

\section{Z-DNA Binding Protein 1}

Z-DNA binding protein 1 (ZBP1), previously known as DLM-1 or DNA-dependent activator of IFN-regulatory factors (DAI), is a stress granule-associated protein, which contains two functional Z-DNA/RNA binding $(Z \alpha)$ domains in its N-terminus [118-121]. In addition to binding Z-DNA, it can also bind left-handed double-stranded Z-RNA and RNA, which adopt Z-RNA-like conformations [122]. ZBP1 has been identified as a putative 
cytosolic DNA sensor and activator for the induction of type I IFNs and other genes involved in innate immunity [123]. Upon binding DNA, ZBP1 dimerizes and recruits TANK-binding kinase 1 (TBK1) and IFN regulatory factor 3 (IRF3) to induce the production of type I IFNs and the NF-кB pathway (Figure 2) [123-125]. Activated ZBP1 can also activate receptor interacting protein kinase 3 (RIPK3) by binding through RIP homotypic interaction motifs (RHIM). This interaction leads to the activation of the mixed lineage kinase-like protein (MLKL), ultimately inducing necroptotic cell death (Figure 2) [126-130]. However, it is still unclear what specific ligand generated during VACV infection is recognized by ZBP1.

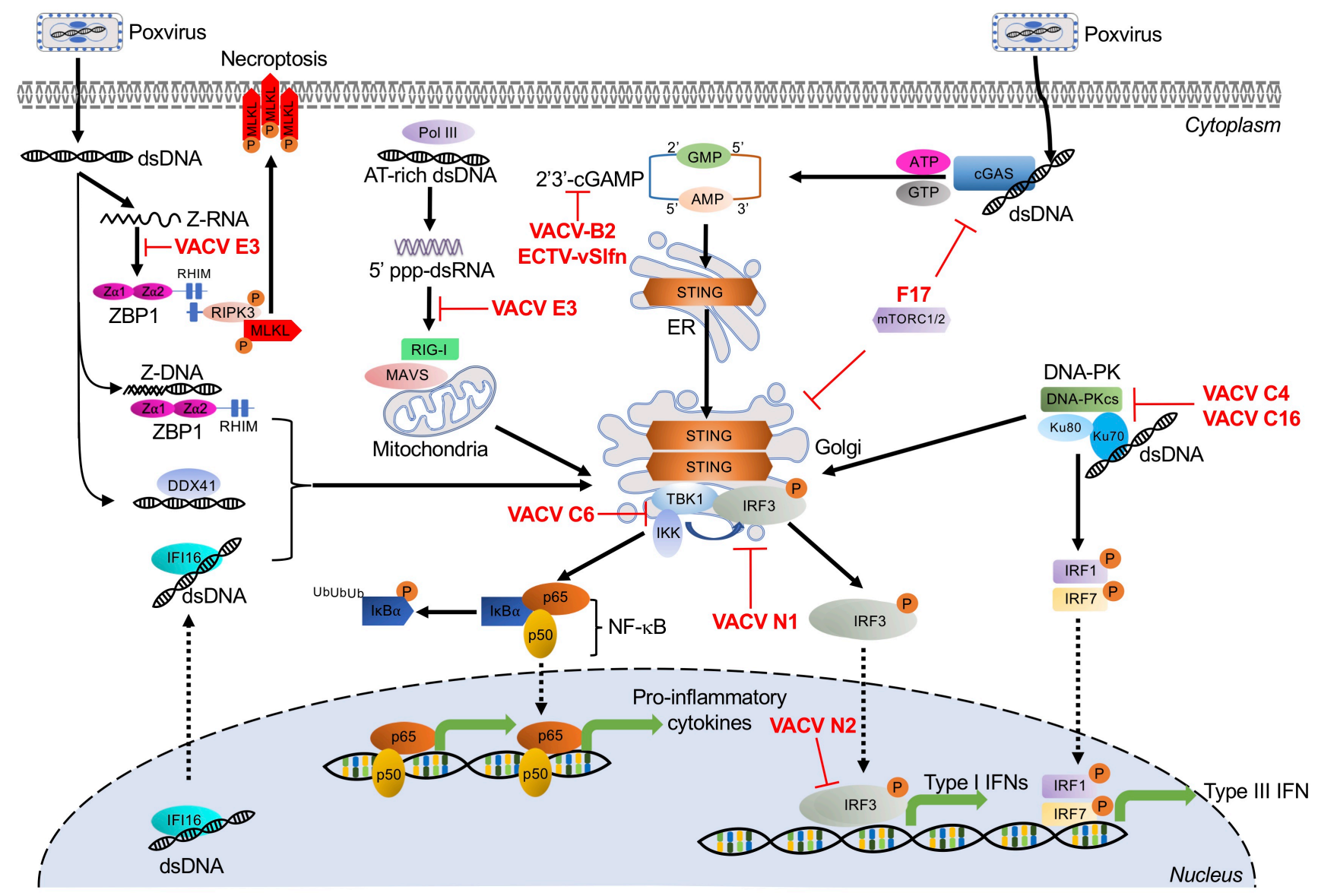

Figure 2. Cytosolic DNA sensor-mediated signaling pathways and poxvirus antagonists. DNA sensors are denoted in black text and the transduction of their triggered signaling cascades are indicated by black arrows. The diverse poxviral inhibitors of these cytosolic DNA sensors are indicated in red. See main text for corresponding details and the underlying molecular mechanisms. Abbreviations used in this figure include ADP: adenosine diphosphate; AMP: adenosine monophosphate; ATP: adenosine triphosphate; cGAS: cyclic GMP-AMP synthase; DDX41: Asp-Glu-Ala-Asp (DEAD) box polypeptide 41; DNA-PK: DNA-dependent protein kinase; DNA-PKcs: DNA-dependent protein kinase catalytic subunit; dsDNA: double-stranded DNA; ECTV: ectromelia virus; ER: endoplasmic reticulum; GMP: guanosine monophosphate; IFI16: interferon- $\gamma$ inducible protein 16; IL-6: interleukin-6; IRF1/3/7: interferon regulatory factor 1/3/7; I $\mathrm{B} \alpha$ : inhibitor $\kappa \mathrm{B} \alpha$; MAVS: mitochondrial antiviral-signaling protein; MLKL: mixed lineage kinase-like; mTORC1/2: mammalian target of rapamycin complex 1/2; MVA: modified vaccinia virus Ankara; NF- $\mathrm{B}$ : nuclear factor kappa B; p50/p65: NF- $\mathrm{B}$ heterodimer p50/p65 subunit; RHIM: RIP homotypic interaction motif; RIG-I: retinoic acid-inducible gene I; RIPK: receptor interacting protein kinase; RNA pol III: DNA-dependent RNA polymerase III; STING: stimulator of interferon genes; TBK1: TRAF family member-associated NF- $\kappa B$ activator (TANK)-binding kinase 1; TNF $\alpha$ : tumor necrosis factor-alpha; TRAF: tumor necrosis factor receptor-associated factor; VACV: vaccinia virus; vSlfn: viral Schlafen; ZBP1: Z-nucleic acid-binding protein 1; Z $\alpha$ : Z-nucleic acid binding domain; $2^{\prime} 3^{\prime}$ cGAMP: $2^{\prime} 3^{\prime}$ cyclic guanosine monophosphate-adenosine monophosphate; 5'ppp-dsRNA: $5^{\prime}$ triphosphate double-stranded RNA. 


\section{Poxvirus Evasion of ZBP1}

VACV E3 contains an amino-terminal $Z \alpha$ domain that is homologous to the ZBP1 $Z \alpha$ domains. E3 is critical for VACV pathogenicity in vivo and for inhibition of the IFN response $[97,131,132]$. It has been proposed that E3 competes with ZBP1 for Z-nucleic acid binding in VACV-infected cells. This hypothesis is supported by the observation that E3 overexpression reduced DNA-mediated induction of IFN $\beta$ responses [124]. In addition, a VACV E3 mutant that lacks the ability to bind Z-DNA is less pathogenic in a wild type mouse infection model, but not in either ZBP1- or RIPK3-deficient mice. However, this pathogenicity could be restored by an E3 chimera expressing the first Z $\alpha$ domain of ZBP1 or ADAR1 [126,132]. Overexpression of E3 was also described to reduce DNA-mediated induction of IFN $\beta$ responses [124]. During VACV infection, only full-length E3, but not a $\mathrm{Z} \alpha$-deleted E3 mutant $(\triangle 83 \mathrm{~N})$, prevented ZBP1-mediated RIPK3-dependent necroptosis. Importantly, VACV-E3L $\triangle 83 \mathrm{~N}$ showed strong attenuation in wild type mice, but not in either ZBP1-, RIPK3-, or DAI-deficient mice [126]. While most mammalian poxviruses contain E3L orthologs, some of these orthologs, including those from monkeypox virus and myxoma virus, do not encode functional $\mathrm{Z} \alpha$ domains [85]. In myxoma virus and rabbit fibroma virus, which only productively infect rabbits and hares, the complete $\mathrm{Z} \alpha$ domainencoding DNA is missing from their E3 orthologs [85] and is therefore not predicted to inhibit RIPK3-dependent necroptosis.

\section{DNA-Activated Sensors and Poxvirus Antagonists}

Cytosolic DNA sensing mainly induces transcription of type I interferons but can also initiate NF-kB-dependent proinflammatory cytokines, which constitute an important frontline of antiviral defense against DNA viruses. Initial research demonstrated that multiple ligands, such as long poly(dA:dT), and dsDNA oligonucleotides led to the activation of the IRF3 pathway and subsequent type I interferon responses [133,134]. More recently, investigations have focused on defining the upstream DNA receptors, and this effort has advanced considerably over the past decade [135]. Along with TLR9, discussed in a separate section, this effort has led to the identification of multiple DNA receptors, of which cyclic GMP-AMP synthase (cGAS), DNA-dependent RNA polymerase III (PolIII), interferon- $\gamma$ inducible protein 16 (IFI16), DNA-dependent protein kinase (DNA-PK), and DEAD box polypeptide 41 (DDX41) have been implicated in detecting poxviruses (Figure 2).

\subsection{Cyclic GMP-AMP Synthase}

Cyclic GMP-AMP synthase (cGAS) belongs to the oligoadenylate synthase (OAS) protein family and recognizes DNA in the cytosol [136]. Upon binding DNA, cGAS dimerizes and catalyzes the synthesis of $2^{\prime}, 3^{\prime}$ cyclic guanosine monophosphate-adenosine monophosphate (2', $3^{\prime}$ cGAMP), a 2'-5'-linked cyclic dinucleotide second messenger [137]. cGAMP binds to and activates the adaptor protein STING (stimulator of interferon genes). In turn, STING activates the protein kinases IкB $\alpha$ kinase (IKK) and TANK-binding kinase 1 (TBK1), leading to the induction of interferons and cytokines through activation of NF- $k B$ and IRF3, respectively (Figure 2) [136,138-141].

The cGAS-STING axis is an important recognition pathway for multiple DNA viruses, including poxviruses. In ectromelia virus (ECTV)-infected inflammatory monocytes, STING played an essential role in inducing interferon production through the activation of IRF7 and NF- $\kappa B$ signaling. Mice deficient in IRF7- and NF- $\kappa B$ were susceptible to ECTV infection [142]. Additional work demonstrated that cGAS is a key sensor for ECTV infection. Knockdown of either cGAS or STING decreased transcription of IFN $\alpha$ and IFN $\beta$ in L929 cells infected with ECTV. This phenotype was also observed in cGAS- or STING-deficient mice [143]. The cGAS-STING axis has also been shown to detect VACV infection. IFN $\beta$ induction after VACV infection was largely abolished in cGAS- or STINGdeficient mouse lung fibroblasts and dendritic cells [144]. In line with this observation, the cGAS-STING axis was necessary for type I IFN production in MVA-infected murine bone 
marrow-derived cDCs. Furthermore, cGAS and STING deficiency abolished TBK1 and IRF3 phosphorylation in these cells, and mice lacking STING or IRF3 showed decreased type I IFN expression compared to wild type mice in response to MVA infection [145].

\subsubsection{Poxvirus Evasion of cGAS}

Poxviruses encode several proteins that target cGAS-STING at different steps in the pathway (Figure 2). STING phosphorylation and dimerization were suppressed during VACV-COP and -WR infection, indicating the existence of inhibitors that target this pathway upstream of STING [146]. The poxvirus protein F17, a late structural protein, has been reported to help evade cytosolic cGAS sensing. In response to infection with VACV lacking F17, cGAS mediated IRF activation and interferon-stimulated gene (ISG) responses in both macrophages and lung fibroblasts [147]. F17 bound and sequestered Raptor and Rictor, which are regulators of mammalian target of rapamycin complexes mTORC1 and mTORC2, respectively. F17-mediated mTOR dysregulation blocked STING-mediated ISG induction and antiviral responses, in part, through mTOR-dependent cGAS degradation [148]. More recently, VACV B2 was shown to degrade the second messenger $2^{\prime}, 3^{\prime}$-cGAMP, and this family of enzymes has been named "poxins". Deleting VACV poxin led to significant attenuation in a skin infection mouse model, although, interestingly, IFN $\beta$ levels were not increased, suggesting that poxins act by preventing cGAMP spread more than they prevent downstream effector production [149].

Poxin-encoding genes are found in many other poxviruses but are notably inactivated in VARV and VACV-MVA. In VACV and the closely related horsepox and rabbitpox viruses, the poxin domain is found by itself. However, in most orthopoxviruses, the poxin domain is found in combination with a Schlafen (Slfn) family-related domain [149]. In ECTV, this protein was called vSlfn. vSlfn-deficient ECTV was strongly attenuated in mouse infection models and unable to block the activation of STING, TBK1, and IRF3 in macrophages and correlated with a strong IFN response [150].

\subsubsection{Poxvirus Evasion of STING}

It was found that DNA-induced activation of STING and IRF3 can be inhibited by infection with cowpox virus, ECTV, and VACV strains Copenhagen (COP) and Western Reserve (WR), but not by MVA [146]. Both TBK1 and IRF3 are key downstream components of the STING pathway, which mediate the IFN response. These downstream effectors are also targeted by poxviral antagonists such as VACV-C6, N1, N2, and E3 proteins (Figure 2). VACV-C6, N1, and N2 belong to a family of B cell CLL/lymphoma 2 (Bcl-2)-like proteins. C6 inhibits the IFN $\beta$ response induced by poly $(\mathrm{dA}: \mathrm{dT})$ DNA by blocking the activation of TBK1 and IKK $\varepsilon$ while inhibiting translocation and activation of IRF3 [151]. VACV N1 was shown to directly associate with TBK1 to inhibit IRF3-mediated IFN $\beta$ responses. As an example of this effect, repairing the defective N1L gene in MVA abrogated the type I IFN response relative to infection with unaltered MVA. This IFN reduction coincided with reduced levels of TBK1 and IRF3 phosphorylation [145]. The early nuclear protein $\mathrm{N} 2$ acts further downstream in this pathway, inhibiting an IRF3-specific reporter (ISG56) response that was induced by overexpression of TBK1 or by poly(dA:dT) DNA stimulation. In addition, N2 also inhibited TBK1-elicited IFN $\beta$ promoter responses [152].

\subsection{RNA Polymerase III}

DNA-dependent RNA polymerase III (Pol III) is a ubiquitous enzyme, which mainly resides in the nucleus, where it fulfills most of its cellular functions, including transcription of short untranslated RNAs, including transfer RNAs, 5S rRNA, and U6 spliceosomal RNA, using DNA as a template. However, Pol III may also localize to the cytosol, where it acts as a DNA sensor and engages the RIG-I-mediated pathway [106]. In the cytosol, Pol III serves as a DNA sensor of several pathogens, including Legionella pneumophila, herpes simplex virus 1 (HSV-1), Epstein-Barr virus, and VACV [106,117]. It detects cytosolic ATrich dsDNA through its DNA binding regions. Pol III then transcribes the DNA template 
into $5^{\prime}$-triphosphate-containing dsRNA, which activates RIG-I and leads to the induction of type I interferons and NF-kB activation (Figure 2) [106,153,154].

Poxvirus Evasion of Pol III

To date, the only described inhibitor of Pol III dsDNA sensing is VACV E3. In 293T cells transfected with full-length E3, poly(dA:dT) DNA induced IFN $\beta$ expression, and NF- $\mathrm{kB}$ activity was abolished. Furthermore, the dsRBD-containing C-terminus alone was sufficient to inhibit these responses, whereas the $\mathrm{Z} \alpha$ domain-containing $\mathrm{N}$-terminus was dispensable [117].

\subsection{Interferon- $\gamma$ Inducible Protein 16}

The intracellular DNA sensor interferon- $\gamma$ inducible protein 16 (IFI16) belongs to the pyrin and HIN200 domain (PYHIN) protein family. Although IFI16 contains a nuclear localization signal and is mainly located in the nucleus, it can also be found in the cytosol, where it can recognize single-stranded (ss) DNA and dsDNA [155]. The HIN domain of IFI16 recognizes DNA ligands in a length-dependent manner [156]. Activated IFI16 induced the expression of IFN $\beta$ through IRF3 activation and the production of NF- $\mathrm{kB}$ dependent proinflammatory genes during infection with several DNA viruses, including HIV, HSV-1, and VACV (Figure 2) [155,157-159]. IFN $\beta$ expression induced by transfection with VACV DNA was dependent upon STING, TBK1, and IRF3, but not TLRs, ZBP1, or Pol III. IFI16 physically interacted with STING, and BMDMs lacking STING failed to trigger IFN $\beta$ secretion in response to viral DNA [159]. IFI16 deficiency inhibited IRF3 activationand NF- $\mathrm{KB}$-dependent gene production induced by transfected DNA, and during infection with either MVA or HSV-1 [155,159]. During VACV infection, IFI16 shuttled from the nucleus of keratinocytes to viral factories in the cytosol for viral DNA recognition. Infection with the highly attenuated VACV strain MVA, but not with VACV-WR, induced IFI16dependent CCL5 and ISG56 expression. These data indicate that VACV-WR can inhibit the IFI16 pathway, presumably via one or more of the genes missing in MVA [155]. The precise mechanisms of how VACV modulates IFI16-mediated DNA sensing are unclear, but viral immunomodulators that target downstream signaling of STING likely play a role.

\subsection{DNA-Dependent Protein Kinase}

DNA-dependent protein kinase (DNA-PK) is best studied for its involvement in DNA repair and $\mathrm{V}(\mathrm{D}) \mathrm{J}$ recombination [160]. However, in addition to this well-documented activity, DNA-PK can also recognize cytosolic DNA [161]. As a heterotrimeric complex, DNA-PK is comprised of the catalytic subunit DNA-PKcs and the Ku heterodimer, consisting of Ku70 and Ku80 subunits. Upon exposure to exogenous DNA, Ku70 translocated from the nucleus to the cytosol and triggered the production of type III IFN (IFN $\lambda 1$ ), which involved STING and TBK1 as mediators. This activity was associated with the activation of the transcription factors IRF1, IRF3, and IRF7 (Figure 2) [161,162]. DNA-PK-dependent DNA sensing was shown to contribute to the initiation of the immune response to VACV in fibroblasts. Supporting this contribution, DNA-PK deficiency in either cell lines or mice significantly impaired the induction of IFN $\beta$ and IL-6 in response to infection with MVA or HSV-1 [163].

\section{Poxvirus Evasion of DNA-PK}

VACV expresses two related proteins, called C16 and C4 in the WR strain, that target the DNA-PK-mediated DNA sensing pathway (Figure 2). These proteins share about $54 \%$ amino acid identity in their C-terminal region [164-166]. The C-terminal region of C16 interacts directly with the Ku heterodimer of the DNA-PK complex to prevent DNAPK binding to DNA, ultimately reducing the production of cytokines and chemokines. Consistent with this in vitro observation, mice infected with C16-deficient VACV, produced more cytokines and chemokines than mice infected with wild type VACV [164]. As with $\mathrm{C} 16, \mathrm{VACV}$ protein $\mathrm{C} 4$ also interacts with $\mathrm{Ku}$ and blocks DNA binding through its $\mathrm{C}$ - 
terminal domain, resulting in decreased IRF3 phosphorylation. Additionally, C4 inhibits the recruitment and activation of immune cells and suppresses cytokine production, such as IL-6, both in vitro and in vivo [165]. While C16 and C4 have overlapping functions, viruses with deletions of only one of these proteins were still attenuated in mouse infection models. The two most likely interpretations of these data are that there might be currently unrecognized non-redundant functions between the two proteins, or that C16 and C4 work in tandem by mass action [165].

\subsection{DEAD Box Polypeptide 41}

DEAD box polypeptide 41 (DDX41) was identified as a cytosolic sensor that recognizes diverse pathogen-derived nucleic acids, such as viral dsDNA, cyclic di-GMP, and cyclic di-AMP $[167,168]$. DDX41 is a member of the DEAD-box protein family and is composed of two RecA-like domains (DEADc and HELICc domains) and a zinc finger [169]. Upon binding dsDNA via its DEADc domain, DDX41 associates with STING and initiates the activation of NF-KB and IFN signaling pathways in myeloid dendritic cells (Figure 2) [167].

DDX41 directly recognized a repeating $70 \mathrm{bp}$ motif (VACV 70mer), which is located in the inverted terminal repeat region of the VACV genome $[159,167]$. Knockdown of DDX41 or STING in THP-1 cells abolished the production of IFN $\beta$ and IL-6 in response to either the VACV 70mer or HSV-1 DNA [167]. It is unknown if poxviruses directly target DDX41, but it is possible that poxviral inhibitors that act downstream of STING activation can also interfere with this DDX41-mediated immune response (see Poxvirus Evasion of STING).

\section{Toll-Like Receptor-Mediated Poxvirus Recognition and Poxvirus Antagonists}

Toll-like receptors (TLRs) are a family of PRRs, which derive their name from their homology with the Drosophila Toll gene [170]. In Drosophila, activation of the Toll pathway by ligands from Gram-positive bacteria or fungi triggers cellular immunity and production of antimicrobial peptides [171-173]. Toll-like receptors function as PRRs to initiate signaling cascades important for host defense against many pathogens. There are 13 currently known TLRs in mammals (TLR1 to TLR13), although humans only possess TLRs 1 through 10 [174].

TLRs are type I integral membrane glycoproteins expressed in both immune cells and non-immune cells such as fibroblasts and endothelial cells. These receptors have a common architecture, with an N-terminal extracellular leucine-rich repeat-containing ectodomain, which is responsible for the recognition of PAMPs, a single transmembrane helix, and a C-terminal cytoplasmic Toll/interleukin-1 receptor (TIR) homology domain [175]. TLRs localize to the plasma membrane of the cell surface (TLRs 1, 2, 4, 5, 6, and 10) or to various intracellular compartments (TLRs 3, 7, 8, 9, 11, 12, and 13), such as the endoplasmic reticulum (ER), endosome, lysosome, and endolysosome [176]. This cellular localization is one determinant of the PAMPs sensed by TLRs [176]. Once activated, TLRs typically activate downstream effectors through either adaptor proteins, typically myeloid differentiation primary response gene $88(\mathrm{MyD} 88)$ or TRIF.

TLR2/6, TLR4, TLR8, and TLR9 recruit myeloid differentiation primary response gene 88 (MyD88) to transduce their signaling cascades [41]. Activation of MyD88-dependent signaling induces proinflammatory cytokines and chemokines (Figure 3). TLR8-MyD88 and TLR9-MyD88 signaling pathways are also engaged in IFN induction through IFN regulatory factor 7 (IRF7) activation in dendritic cell (DC) subsets, such as the plasmacytoid DCs (pDCs) [177]. MyD88 recruits and interacts with interleukin 1 receptor-associated kinase 4 (IRAK4) to form a structure known as the Myddosome along with two other IRAK family members, IRAK1 and IRAK2. This complex activates tumor necrosis factor receptorassociated factor 6 (TRAF6) [178]. TRAF6-induced activation of TGF- $\beta$ activated kinase 1 (TAK1) subsequently phosphorylates the IKK $\beta$ subunit of the canonical IKB kinase (IKK) complex [179], resulting in ubiquitination and proteasomal degradation of $\mathrm{I}_{\kappa} \mathrm{B} \alpha$ and release of NF-кB [180], leading to the production of proinflammatory cytokines (Figure 3) [181]. Notably, Toll/interleukin 1 receptor (TIR) domain-containing adapter protein (TIRAP, 
also known as Mal) and TRIF-related adaptor molecule (TRAM) are further required for bridging MyD88 to TLR2/ 6 and TLR4.

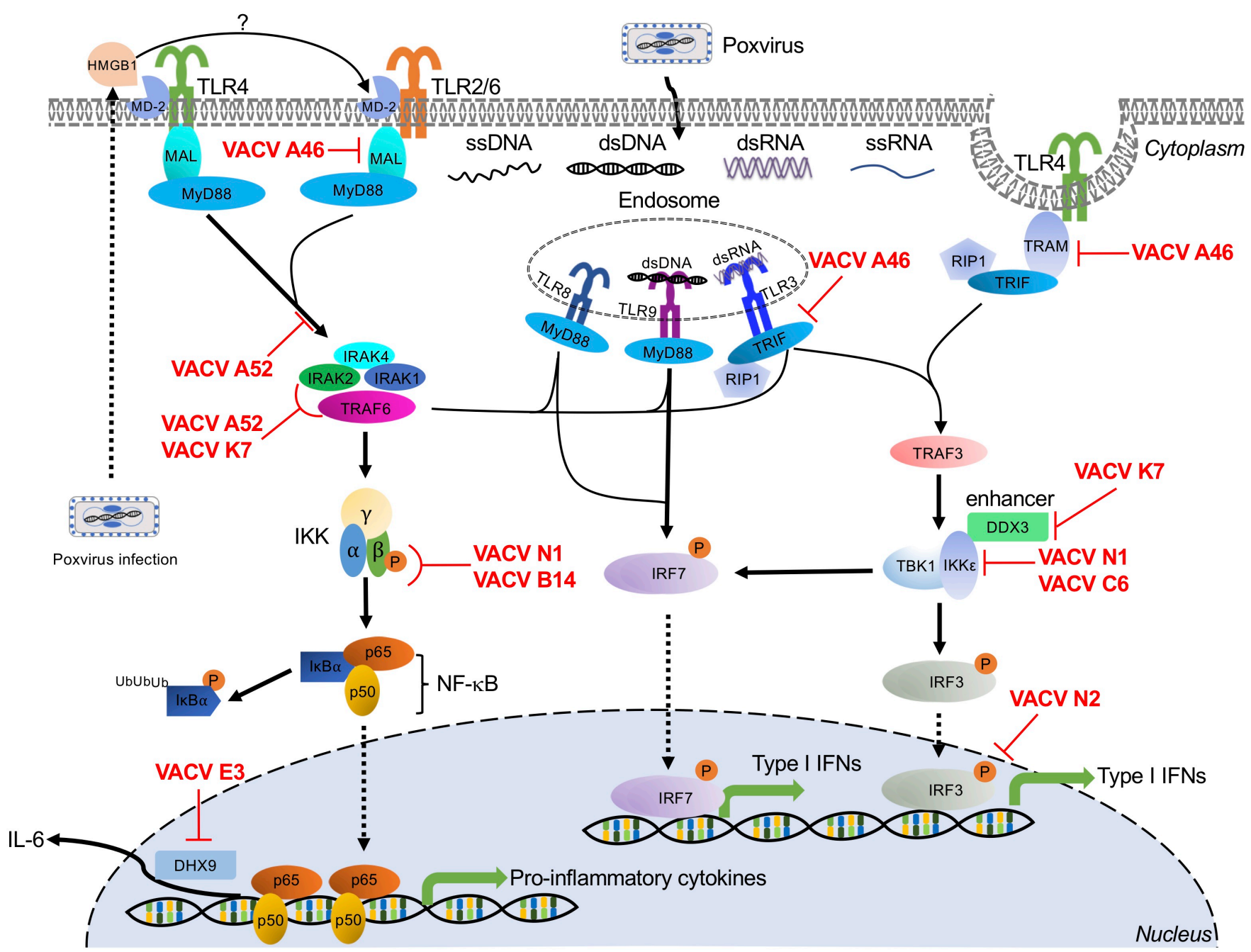

Figure 3. TLR family-mediated signaling pathways and poxvirus antagonists. TLR sensors involved in the recognition of poxviral infections are indicated in their subcellular localization. The signaling cascades induced by these TLRs are denoted by black arrows to indicate transduction or activation. Poxvirus-encoded viral antagonists and their targeted signaling molecules are shown in red. Abbreviations used in this figure include DDX3: Asp-Glu-Ala-Asp (DEAD) box polypeptide 3; DHX9: DExH-Box helicase 9; dsDNA: double-stranded DNA; dsRNA: double-stranded RNA; HMGB1: high mobility group

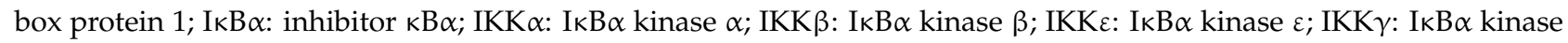
$\gamma$; IL-6: interleukin-6; IRAK1/2/4: interleukin-1 receptor-associated kinase 1/2/4; IRF3/7: interferon regulatory factor 3/7; Mal: myD88-adapter-like; MD-2: myeloid differentiation factor 2; MyD88: myeloid differentiation primary response gene 88; NF-kB: nuclear factor kappa B; p65/p50: NF-kB heterodimer p50/p65 subunit; RIP1: receptor-interacting protein 1; ssDNA: single-stranded DNA; ssRNA: single-stranded RNA; TBK1: TRAF family member-associated NF- $\mathrm{kB}$ activator (TANK)-binding kinase 1; TLR2/3/4/8/9: Toll-like receptor 2/3/4/8/9; TNF $\alpha$ : tumor necrosis factor-alpha; TRAF3/6: tumor necrosis factor receptor-associated factor 3/6; TRAM: TRIF-related adapter molecule; TRIF: Toll/interleukin-1 receptor domain-containing adapter-inducing interferon- $\beta$; VACV: vaccinia virus.

The TRIF-dependent pathways are initiated through TLR3 and endosomal TLR4 and induce both inflammatory responses and type I IFNs through activation of TRAF6 or TRAF3, respectively [42]. TRIF associates with TRAF6 and RIP1 to activate the classical IKK complex through the activation of TAK1 kinase complex, resulting in the production of NF-кB-dependent proinflammatory cytokines and chemokines [181]. In contrast, TRIF interacts with TRAF3 to recruit the noncanonical IKK-related kinases TBK1 and IKK $\varepsilon$ for 
phosphorylation and activation of IRF3/IRF7, resulting in the subsequent induction of type I and type III IFNs (Figure 3) [182].

Several TLRs play roles in poxvirus infections, including endosomal TLR3, TLR8, and TLR9, and membrane-bound extracellular TLR2 and TLR4 (Figure 3).

\subsection{TLR3}

TLR3 localizes to the endosome and was the first characterized TLR to recognize nucleic acid [183]. The primary ligand of TLR3 dsRNA is recognized via the N-terminal ectodomain (ECD) [183-185]. After binding dsRNA, downstream signaling transduction is mediated through the TIR domain-containing adaptor-inducing interferon- $\beta$ (TRIF) [186]. Activation of the TLR3-TRIF pathway leads to the production of NF- $\kappa \mathrm{B}-$ dependent proinflammatory cytokines, and type I and type III IFNs (Figure 3) [183].

Paradoxically, when infected with VACV, TLR3 ${ }^{-1-}$ mice showed decreased disease morbidity, accompanied by reduced VACV replication in the respiratory tract and impaired viral dissemination [25]. This TLR3 deficiency did not change the level of IFN $\beta$ but did reduce the levels of inflammatory cytokines, including IL-6, TNF $\alpha$, and monocyte chemoattractant protein-1 (MCP-1/CCL2). These cytokine increases suggest that the increased morbidity and viral dissemination observed in TLR3-competent mice may be mediated through NF-kB-dependent inflammatory cytokines [25]. However, TLR3 has also been shown to improve post-exposure vaccine efficacy in response to ECTV infection in mice. BALB/c mice infected with ECTV can be cured by post-exposure vaccination with either the VACV-Lister or MVA strains up to three days after infection. However, postexposure treatment with poly(I:C), an agonist of TLR and other dsRNA-binding proteins, either alone or in combination with traditional vaccination improved the efficacy of this treatment regimen by modulating TLR3 activation and IFN $\alpha$ induction [187]. Thus, the antiviral activity of TLR3 is complex and merits further investigation.

\section{Poxvirus Evasion of TLR3}

Poxviruses encode multiple Bcl-2-like proteins that target the TLR3 pathway, including A52, A46, N1, B14, K7, N2, and C6 proteins (Figure 3). Intriguingly, the first five of these proteins share homology, although as described below, they inhibit TLR3 through distinct mechanisms. A52 was shown to block TLR3-mediated activation of NF- $\mathrm{kB}$ induced by poly(I:C) stimulation through interaction with both interleukin 1 receptor-associated kinase 2 (IRAK2) and tumor necrosis factor receptor-associated factor 6 (TRAF6), disrupting the Mal-IRAK2 signaling complex or TRAF6-TAB1-containing complex, respectively [188]. In response to poly(I:C), A46 was directly associated with TRIF, which acted as a TIR adapter for TLR3 signaling, in order to inhibit IRF3 activation and gene induction [189]. However, in the presence of poly(I:C), N1 physically interacted with components of the IKK complex and also associated with IKK $\varepsilon$ and TBK1, thereby inhibiting NF- $\mathrm{KB}$ activation and IRF3mediated IFN $\beta$ responses [190]. B14, an immediate-early gene product of VACV, prevented phosphorylation of IKK $\beta$, a component of the IKK complex, resulting in inhibition of NF- $\mathrm{KB}$ signaling induced by poly(I:C) [191,192]. K7 has been shown to interact with DEAD-box RNA helicase (DDX3) to inhibit TRIF-induced IRF3/7 activation and also prevented IFN $\beta$ promoter induction at the level of TBK1/IKKe [193]. VACV N2 localized to the nucleus and functionally inhibited IRF3 activity after translocation of IRF3 into the nucleus. Ultimately, this N2-IRF3 interaction decreased activation of the IFN $\beta$ promoter in response to poly(I:C) stimulation [152]. Finally, C6 has been reported to be a multifunctional interferon antagonist during VACV infection. In the context of the TLR3 pathway, C6 prevented TBK1- and IKK $\varepsilon$ dependent IRF3 activation, resulting in inhibition of IFN $\beta$ promoter activation induced by poly(I:C) [151,152].

\subsection{TLR8}

TLR8 is broadly expressed in the endosomes of myeloid cells, such as monocytes, macrophages, and myeloid dendritic cells (DCs) [194,195]. TLR8 is non-functional un- 
til it undergoes proteolytic processing to generate a functional receptor in the endosome [195]. Activation of this Toll-like receptor is traditionally mediated through recognition of uridine- and guanosine-rich single-stranded RNA (ssRNA) of either bacterial or viral origin $[196,197]$. However, a recent report has shown that murine TLR8 can be activated by poxviral DNA or by synthetic poly(A) and poly(T) oligodeoxynucleotides both in vitro and in vivo. Either VACV infection or VACV DNA activated an NF-KB reporter expressed by HEK293 cells that expressed murine TLR8, but not in cells expressing murine TLR7. Similarly, siRNA-mediated knockdown of TLR8 reduced the secretion of IFN $\alpha$ in pDCs [198]. However, the underlying mechanism is yet to be determined.

Regardless of the ligand, binding transduces signaling through MyD88, ultimately resulting in the induction of IRF7 activation, IFN production, and NF- $\mathrm{kB}$-dependent proinflammatory responses (Figure 3). In addition, VACV infection-induced IFN $\alpha$ production by $\mathrm{pDC}$ in vitro and in vivo and TLR8-dependent $\mathrm{pDC}$ activation played an important role in the control of VACV infection in vivo [198].

\section{Poxvirus Evasion of TLR8}

VACV E3 has been reported to target TLR8-dependent pathways. In human monocytes, E3 reduced the expression of TLR8-dependent cytokines, including proinflammatory cytokines such as TNF $\alpha$ and IL-6, and chemokines such as interferon gamma-induced protein 10 (IP-10), and chemokine (C-C motif) ligand 5 (CCL5, also known as RANTES). In addition, E3 directly interacted with DExH-Box helicase 9 (DHX9) to antagonize IL-6 promoter activation [199].

\subsection{TLR9}

TLR9 was the first identified DNA sensor. It is localized in endosomes in a variety of cells including plasmacytoid dendritic cells (pDCs), B cells, neutrophils, monocytes, and some non-immune cells [200,201]. TLR9 undergoes proteolytic cleavage of its ectodomain to recognize unmethylated cytosine-guanosine $(\mathrm{CpG})$-rich DNA derived from bacteria or viral genomic dsDNA [200,202-204].

As the primary DNA-sensing TLR, TLR9 has been implicated in the response to multiple poxvirus infections. For example, TLR9 depletion dramatically decreased mouse survival after ECTV infection, which required TLR9 expression in DCs [26]. TLR9 depletion in these mice abolished ECTV-induced DC maturation and IFN $\alpha$ production, highlighting the important role of TLR9 when controlling ECTV infection [26]. In this ECTV model, the TLR9-MyD88-IRF7 pathway was essential for proinflammatory cytokine expression in $\mathrm{CD}_{11} \mathrm{c}^{+}$cells and for the recruitment of inflammatory monocytes to the draining lymph node [142].

In response to MVA infection, TLR9-deficient or MyD88-deficient murine cDCs showed decreased production of IFN $\alpha$ and IFN $\beta$ compared to wild type cDCs [145]. TLR9 has also been implicated in the host response to fowlpox virus and MYXV through the above-described MyD88 signal transduction cascade [205,206].

\section{Poxvirus Evasion of TLR9}

To date, VACV E3 is the only described viral antagonist of the TLR9 pathway [206]. In cells treated with CpG-containing DNA, a TLR9 agonist, wild type VACV significantly inhibited IFN $\beta$, TNF, and IL-12p70 (IL-12) production in murine pDCs. In contrast, infecting these cells with VACV lacking E3L reduced this inhibitory effect, which could be rescued by co-infection with wild type VACV. These results were also phenocopied if only the N-terminal Z-DNA binding $(\mathrm{Z} \alpha)$ domain of E3 was deleted, demonstrating that this domain is important for TLR9 pathway inhibition [206].

\subsection{TLR4}

TLR4 was identified as a human Toll homolog in 1997 [207]. TLR4 predominantly recognizes bacterial lipopolysaccharide (LPS), mannuronic acid polymers, and teichuronic 
acid. TLR4 has also been shown to recognize viral glycoproteins, fusion proteins, and damage-associated molecular patterns (DAMPs) [208-212]. Whether TLR4 directly recognizes poxvirus ligands is not yet clear. One possibility is that TLR4 is indirectly activated after poxvirus infections. Previous work has demonstrated that infection with either VACV strains WR or MVA can lead to the extracellular release of high mobility group box protein 1 (HMGB1). Outside the cell, HMGB1 binds to myeloid differentiation factor 2 (MD-2), the extracellular adaptor of TLR4, to activate this pathway [213-215]. There is also some evidence that TLR4 may recognize a viral protein, potentially on the virion surface, rather than ligands released or generated during infection [216]. It is currently unclear if either or both of these mechanisms are the primary mode of TLR4 activation by poxviruses. After ligand binding, TLR4 dimerizes and initiates a signaling cascade via TLR adapter molecules MyD88 adaptor-like (Mal)/TIRAP, MyD88, TRAM, and TRIF, resulting in the production of inflammatory cytokines and type I IFNs (Figure 3) [217]. In response to VACV infection, TLR4 provided maximal protection against pulmonary VACV infection in a mouse model. Surprisingly, TLR4 dampened the cytokine response of bone marrow macrophages to VACV, and TLR4 deficiency promoted an increase in IFN $\beta$ and IL-6 production in the lungs [216].

\section{Poxvirus Evasion of TLR4}

VACV proteins A46, A52, K7, and N1 have been implicated in TLR4 evasion (Figure 3). A46 and A52 share amino acid sequence similarity with the Toll/interleukin-1 receptor (TIR) domain. The VACV A46 protein directly interacts with the TLR4, MyD88, Mal, TRIF, and TRIF-related adaptor molecule (TRAM), disrupting receptor-adaptor interactions and inhibiting downstream signaling [218-222]. A46-deficient VACV showed attenuated virulence in a murine intranasal infection model [189]. A52 targets TLR4 signaling, potently suppressing both IL-1- and TLR4-mediated NF- $\mathrm{KB}$ activation by mimicking the dominant negative effect of a truncated version of MyD88 [223]. VACV K7 blocks both IRAK2 and TRAF6 activation to inhibit the TLR4-NF-KB signaling axis [193]. Finally, N1 has been shown to target the TRAF6-TBK1-IKK complex, interacting with IKK $\alpha$ and IKK $\beta$ to block NF-KB responses [190].

\subsection{TLR2}

TLR2, first identified in 1998 [170], is expressed on the surface of immune cells, such as monocytes, macrophages, dendritic cells, and NK cells. On the cell surface, TLR2 forms heterodimers with either TLR1 or TLR6 to recognize a wide array of distinct ligands including lipopeptides and lipoteichoic acid from bacteria, and fungal polysaccharides [224-227]. TLR2 also recognizes multiple viral ligands, including envelope glycoproteins and core proteins from cytomegalovirus, HIV-1, and hepatitis C virus [228-230]. Upon ligand binding, TLR2 interacts with the adaptor protein MyD88, ultimately inducing NF-KB-dependent inflammatory responses (Figure 3). While TLR2 has been implicated in the innate response to VACV infection [202,203], defining the poxvirus ligands is still an ongoing area of research. As with TLR4, poxviruses may indirectly initiate TLR2 signaling through HMGB1 and MD-2. This mechanism was proposed for TLR2 activation by an MVA-vectored tuberculosis vaccine candidate (MVA85A), supported by the observation that treating mouse PBMCs with anti-HMGB1 antibodies reduced in vitro production of chemokine (C-X-C Motif) ligand 2 (CXCL2) [214]. However, the more basic question of whether TLR2 can be activated through this HMGB1/MD-2 axis remains controversial [231,232]. Both VACV and UV-inactivated VACV elicited similar immune responses through the TLR2-MyD88 pathway [24]. TLR2 activation by UV-inactivated viruses that should not induce cell death and thus HMGB1 release suggests that TLR2 activation may instead be mediated by direct binding of an as yet undescribed poxvirus ligand. TLR2 deficiency in conventional DCs $(\mathrm{cDCs})$ and T cells reduced the secretion of IL-6 in response to VACV infection compared to infected wild type cells [24,233]. Additionally, TLR2-mediated signaling is important for NK cell activation after VACV infection and critical to control VACV infection in mice [234]. 


\section{Poxvirus Evasion of TLR2}

VACV encodes multiple antagonists of TLR2-mediated signaling, including A46, N1, and E3 (Figure 3). A46 and N1 belong to a family of B cell lymphoma 2 (Bcl-2)-like proteins and contain experimentally confirmed Bcl-2 folds $[219,235,236]$. A46 physically interacted with diverse TIR domain-containing adaptor proteins including MyD88, ultimately preventing TLR2-mediated activation of IRF7 and IFN $\beta$ responses [237]. VACV N1 inhibited the TLR2-mediated activation of NF- $\mathrm{KB}$ through a direct association with components of the IKK complex [190,236]. Finally, VACV E3 was described to act downstream of this pathway to interact with the DExD/H-box helicase DHX9 to inhibit DHX9-mediated enhancement of NF-KB-dependent IL-6 promoter activation [199].

\section{Inflammasome Recognition of Poxviruses and Poxvirus Antagonists}

Inflammasomes are multiprotein signaling complexes responsible for the production of proinflammatory cytokines and the induction of pyroptosis, an inflammatory lytic programmed cell death, to halt viral replication and induce nearby cells to adopt antiviral states [238]. Inflammasome activation mediates the conversion of inactive precursor proteins pro-interleukin (IL)- $1 \beta$ and pro-IL-18 into the bioactive forms IL-1 $\beta$ and IL-18, which play important roles in host defense against a variety of bacterial, fungal, and viral infections $[239,240]$. Certain PRRs have been implicated in canonical inflammasome assembly, including NOD-like receptors and AIM2-like receptors [241,242]. After PAMP and cell damage-associated signal recognition, adaptors are recruited, such as apoptosis-associated speck-like protein (ASC) [243]. This process results in cytokine secretion and pyroptosis as proteolytically active caspases mediate the maturation and secretion of proinflammatory cytokines IL-1 $\beta$ and IL-18, while cleavage of gasdermin-D (GSDMD), a key pyroptotic substrate of inflammatory caspases, induces pyroptosis (Figure 4) [244]. Specifically, the inflammasome proteins NACHT, LRR, and PYD domains-containing protein (NLRP3) and AIM2 have been implicated in the recognition of poxvirus infections $[29,30,245]$.

\subsection{The NLRP3 Inflammasome}

NLRP3 acts as the intracellular sensor component of the NLRP3 inflammasome and detects a broad range of both PAMPs and host-derived activating signals (endogenous damage-associated molecular patterns, DAMPs). NLRP3 is expressed in innate immune cells and non-immune cells, including macrophages, neutrophils, and epithelial cells [246]. This sensor is comprised of an N-terminal pyrin domain (PYD), a central NACHT domain, and C-terminal leucine-rich repeat domains. NLRP3 inflammasomes must be primed before they are activated. This priming step can be mediated by a variety of signals including TLR or NLR ligands, which activate NF- $\mathrm{kB}$. NF- $\mathrm{kB}$ then upregulates NLRP3 expression to levels sufficient to permit inflammasome assembly [247-249]. Once the PAMP or DAMP ligand is bound, oligomerized NLRP3 recruits ASC through homotypic PYD-PYD interactions and activates caspase 1 , thereby triggering the secretion of the proinflammatory cytokines IL- $1 \beta$ and IL-18 (Figure 4). During MVA infection, crosstalk between the NLRP3 inflammasome and TLR2-TLR6-MyD88 has been documented to mediate the expression and processing of IL-1 $\beta$ in macrophages both in vivo and in vitro [29]. Furthermore, in a keratinocyte model of MVA infection, IL- $1 \beta$ secretion was reduced in the presence of pyrrolidine dithiocarbamate, BAPTA tetrakis (acetoxymethyl ester), and glibenclamide, suggesting that intracellular $\mathrm{Ca}^{2+}$ levels and $\mathrm{K}^{+}$efflux may be involved in NLRP3 inflammasome activation [250]. 


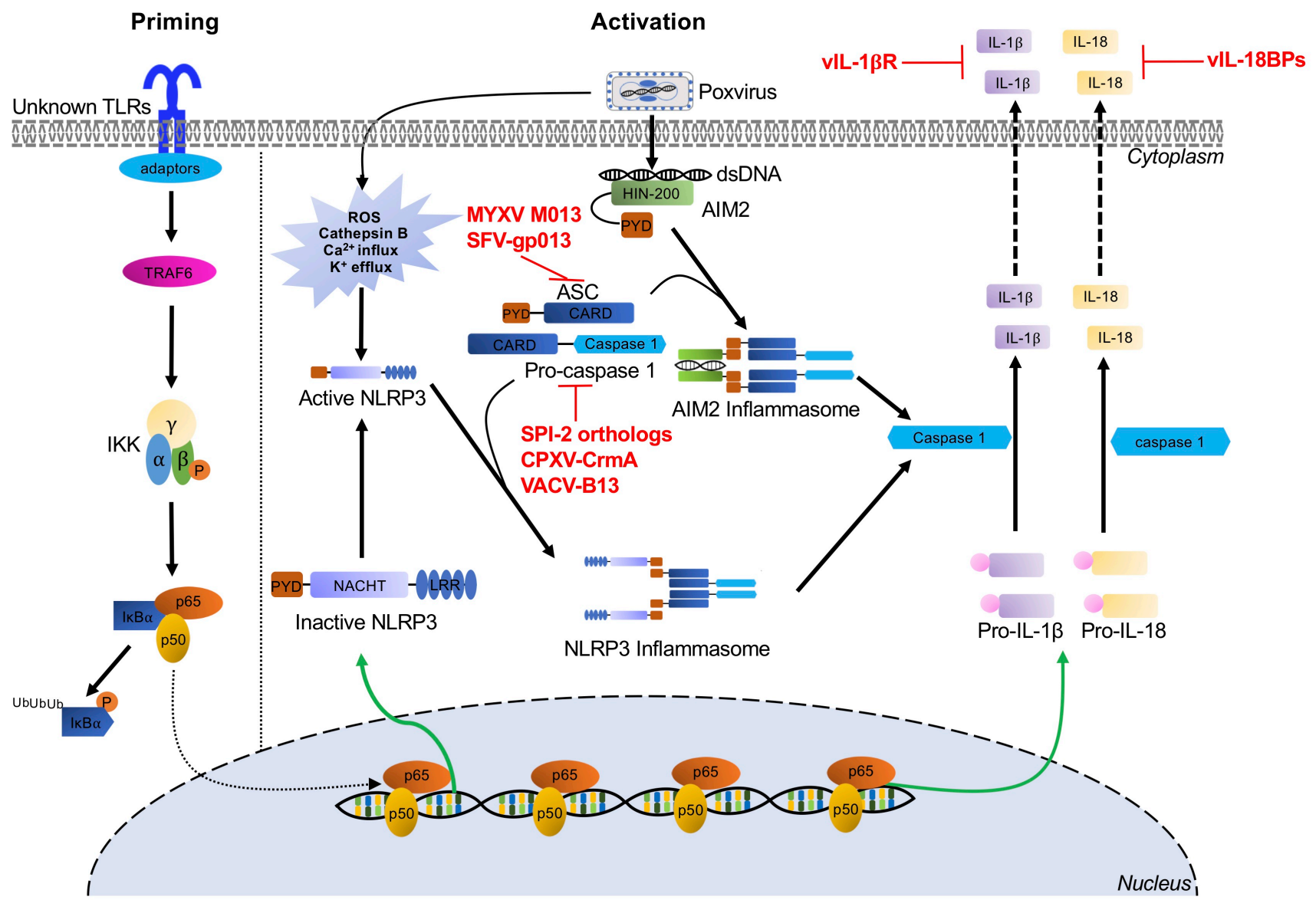

Figure 4. Inflammasome-mediated signaling pathways and poxvirus antagonists. NLRP3 and AIM2 inflammasomemediated recognition of poxvirus infection and the priming and activation pathways for maturation and secretion of IL- $1 \beta$ and IL-18 effectors are indicated by black arrows. Poxviruses express several viral inhibitors or viral homologs of cellular proteins (shown in red) to interfere with these inflammasome pathways at different stages. Abbreviations used in this figure include AIM2: absent in melanoma 2; ASC: apoptosis-associated speck-like protein containing a CARD; CARD: caspase activating and recruiting domains; CPXV: cowpox virus; CrmA: cytokine response modifier A; dsDNA: double-stranded DNA; HIN-200: hematopoietic interferon-inducible nuclear proteins with a 200 amino acid repeat; IKK $\alpha$ : I $\kappa B \alpha$ kinase

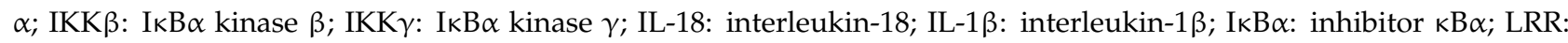
leucine-rich repeats; NF-кB: nuclear factor kappa B; NLRP3: NOD, LRR and pyrin domains-containing protein 3; NOD; nucleotide binding and oligomerization domain; p65/p50: NF- $\mathrm{B}$ heterodimer p50/p65 subunit; PYD: pyrin domain; RFV: rabbit fibroma virus; ROS: reactive oxygen species; SPI-2: serine proteinase inhibitor 2; TLRs: Toll-like receptors; TRAF6: tumor necrosis factor receptor-associated factor 6; VACV: vaccinia virus.

\section{Poxvirus Evasion of the NLRP3 Inflammasome}

To inhibit NLRP3 activity, poxviruses target different stages of inflammasome assembly and processing, as well as inhibiting the secretion or the function of IL-1 $\beta$ and IL-18. Multiple poxviruses encode viral pyrin-only proteins (PYD/vPOP), which have homology with the ASC-PYD domain [18,251]. For example, one of these proteins, MYXV-M013, directly interacts with ASC-1 to inhibit NLRP3-ASC-1 interactions, thereby inhibiting activation of caspase- 1 and the secretion of IL-1 $\beta$ and IL-18 [18,245,252,253]. Similarly, gp013 from rabbit fibroma virus (RFV) interacts with ASC to interfere with PYD-mediated activation of caspase-1 [251]. Poxviruses also encode serine proteinase inhibitor 2 (SPI-2) orthologs, including cytokine response modifier A (CrmA) from cowpox virus and VACVB13. These proteins act as substrate mimics to inhibit caspase-1 activity, thus preventing proteolytic processing of IL-1 $\beta$ [254-256]. Additionally, poxviruses have evolved secreted viral IL-1 $\beta$ receptors (vIL-1 $\beta R$ ), such as VACV-B15, CPXV-B14, and ECTV-191, which prevent IL-1 $\beta$ binding with the host receptors $[257,258]$. Similarly, viral IL-18 binding proteins 
(e.g., molluscum contagiosum virus -54L and VACV-C12) compete with the IL-18 cognate receptor for IL-18 binding [259-261].

\subsection{The AIM2 Inflammasome}

AIM2 belongs to the pyrin and HIN protein (PYHIN) family of proteins and is comprised of an N-terminal PYD domain, which recruits ASC through PYD-PYD interactions, and a C-terminal HIN200 domain, which is essential for recognition and binding cytosolic DNA [262-265]. Upon recognition of DNA, AIM2, ASC, and procaspase 1 form the AIM2 inflammasome. This inflammasome activates caspase 1 to initiate proinflammatory cytokine processing, resulting in maturation and secretion of IL-1 $\beta$ and IL-18 (Figure 4) $[30,266,267]$.

The AIM2 inflammasome has been shown to recognize multiple viral infections including VACV, mouse cytomegalovirus, and influenza A virus [268-271]. For example, in cells derived from AIM2 ${ }^{-/}$mice infected with VACV, IL-1 $\beta$ release and maturation, as well as caspase-1 cleavage, were all reduced $[30,268]$. Similarly, AIM2 knockdown in human primary keratinocytes almost completely abolished IL- $1 \beta$ and IL-18 production during MVA infection. In contrast, NLRP3 knockout only slightly reduced IL-1 $\beta$ secretion [250]. While these data clearly establish a role for the AIM2 inflammasome in response to poxvirus infection, no direct poxvirus inhibitors are currently known. However, the inhibitors of IL-1 $\beta$ and IL-18 activity, discussed in the previous section, are likely effective at preventing the activity of these downstream effectors of AIM2 inflammasome activation.

\section{Conclusions and Outlook}

In this review, we have discussed multiple PRRs and their roles in sensing poxviruses infections and subsequently initiating innate immune responses. Individual PRRs have unique molecular mechanisms for sensing ligands and triggering antiviral responses via diverse adapters and effectors. Furthermore, redundancy, cooperation, and crosstalk among the various PRRs increase this complexity. This crosstalk and redundancy in immune pathways are also reflected in the viral antagonists, with multiple PRR pathways targeted by the same viral proteins. For example, E3 sequesters the dsRNA and blocks the activation of PKR, OAS/RNase L, and TLRs $[68,95,199,206]$. However, it is currently an open question as to whether these multiple functions, for E3 and other antagonists, are truly redundant, or if there are situational differences in the activity of E3 against various pathways. Thus, the overall picture of host recognition of poxviruses is multifaceted and far from clear. Investigation of the cooperation and crosstalk between PRRs will help define the innate immune network(s) elicited by these various PRRs both individually and in combination.

On the other side of this battle, the specific poxviral ligands are not yet known for all of these PRRs. Identification of these ligands, characterization of their structures or motifs, and their interactions with the sensors themselves are necessary to reveal how the signal is initiated by receptors during infection of poxviruses. Furthermore, the molecular mechanisms underlying cell type-specific or virus-specific recognition and signaling by certain PAMPs during poxvirus infections are still largely unknown. Finally, it is becoming more apparent that the diversity in the poxvirus family is also reflected by the range of activities discovered for individual viral gene orthologs, and their implications for viral host range and virulence. This observation is most strongly supported for rapidly evolving genes such as viral immune regulators and their implications for virus host range and virulence $[4,72,78,272]$. Therefore, the data presented in this view representing the response to a handful of poxviruses may not capture the full spectrum of poxvirus responses, and viral orthologs from other poxviruses should also be examined. 
Author Contributions: Conceptualization: H.Y., G.B. and S.R.; writing—original draft: H.Y.; writingreview and editing (H.Y., R.C.B., G.B. and S.R.). All authors have read and agreed to the published version of the manuscript.

Funding: AI114851 and AI146915 (S.R.), AI135257 (G.B.), and T32AI060555 (R.C.B.) from National Institutes of Health.

Acknowledgments: We thank Jeannine Nicole Stroup, Chorong Park, Ana Maria Stoian, Anak Agung Dewi Megawati, Shefali Mrinal Banerjee, and Chi Zhang for discussions and suggestions. We apologize to colleagues whose work could not be cited because of space limitations.

Conflicts of Interest: The authors declare no conflict of interest.

\section{Abbreviations}

ADAR1: adenosine deaminase acting on RNA 1; ADP: adenosine diphosphate; AIM2: absent in melanoma 2; AMP: adenosine monophosphate; AP1: activator protein 1; ASC: apoptosis-associated speck-like protein containing a CARD; ATP: adenosine triphosphate; Bcl-2: B cell CLL/lymphoma 2; CARD: caspase activation and recruitment domains; CCL5: chemokine (C-C motif) ligand 5; cGAS: cyclic GMP-AMP synthase; CNPV: canarypox virus; COP: Copenhagen; CPXV: cowpox virus; CPXV: cowpox viruses; CREP: constitutive repressor of eIF2 $\alpha$ phosphorylation; CrmA: cytokine response modifier A; CTD: carboxy-terminal domain; CXCL2: chemokine (C-X-C Motif) ligand 2; DAMPs: damage-associated molecular patterns; DDX3: Asp-Glu-Ala-Asp (DEAD) box polypeptide 3; DDX41: Asp-Glu-Ala-Asp (DEAD) box polypeptide 41; DHX9: DExH-Box helicase 9; DNA-PK: DNA-dependent protein kinase; DNA-PKcs: DNA-dependent protein kinase catalytic subunit; dsDNA: double-stranded DNA; dsRBD: dsRNA binding domain; dsRNA: double-stranded RNA; ECTV: ectromelia virus; eIF2: eukaryotic translation initiation factor 2; eIF2B: eukaryotic translation initiation factor $2 \mathrm{~B}$; eIF2 $\alpha$ : alpha-subunit of the eukaryotic translation initiation factor 2; ER: endoplasmic reticulum; GADD34: growth arrest and DNA damage-inducible protein 34; GDP: guanosine diphosphate; GMP: guanosine monophosphate; GTP: guanosine-5'-triphosphate; HSV-1: herpes simplex virus $1 \mathrm{HIN-200:} \mathrm{hematopoietic} \mathrm{interferon-inducible} \mathrm{nuclear} \mathrm{proteins} \mathrm{with}$ a 200 amino acid repeat; HMGB1: high mobility group box protein 1; IFI16: interferon- $\gamma$ inducible protein 16; IFNAR: type I interferon receptor; IFNs: interferons; IKK $\alpha$ : IKB $\alpha$ kinase $\alpha$; IKK $\beta$ : IKB $\alpha$ kinase $\beta$; IKK $\varepsilon$ : IкB $\alpha$ kinase $\varepsilon$; IKK $\gamma$ : IкB $\alpha$ kinase $\gamma$; IL-18: interleukin-18; IL-1 $\beta$ : interleukin-1 $\beta$; IL-6: interleukin-6; IRAK1/2/4: interleukin-1 receptor-associated kinase 1/2/4; IRF1/3/7: interferon regulatory factor $1 / 3 / 7$; ISGs: IFN-stimulated genes; $\mathrm{I} \kappa \mathrm{B} \alpha$ : inhibitor $\kappa \mathrm{B} \alpha$; KD: kinase domain; LPS: lipopolysaccharide; LRRFIP1: leucine-rich repeat flightless-interacting protein 1; Mal: myD88adapter-like; Malp2: macrophage-activating lipopeptide 2; MAVS: mitochondrial antiviral-signaling protein; MCP1: monocyte chemoattractant protein 1; MD-2: myeloid differentiation factor 2; MDA5: melanoma differentiation-associated protein 5; MIP2: macrophage inflammatory protein 2; MLKL: mixed lineage kinase-like; MRE11: meiotic recombination 11; mTORC1/2: mammalian target of rapamycin complex 1/2; MVA: modified vaccinia virus Ankara; MyD88: myeloid differentiation primary response gene 88; MYXV: myxoma virus; NF-kB: nuclear factor kappa B; NLRP3: NOD-, LRRand pyrin domain-containing protein 3; NOD; nucleotide binding and oligomerization domain; OAS: 2'-5'-oligoadenylate synthetases; OASL: OAS like; $\mathrm{p} 65$ / p50: NF- $\mathrm{kB}$ heterodimer $\mathrm{p} 50 / \mathrm{p} 65$ subunit; PAMPs: pathogen-associated molecular patterns; PKR: protein kinase R; PRRs: pattern recognition receptors; PYD: pyrin domain; LRR: leucine-rich repeats; PYHIN: pyrin and HIN domain; RFV: rabbit fibroma virus; RHIM: RIP homotypic interaction motif; RIG-I: retinoic acid-inducible gene I; RIP1: receptor-interacting protein 1; RIPK: receptor interacting protein kinase; RLRs: RIG-I-like receptors; RNA pol III: DNA-dependent RNA polymerase III; RNase L: ribonuclease L; ROS: reactive oxygen species; SPI-2: serine proteinase inhibitor 2; ssDNA: single-stranded DNA; ssRNA: single-stranded RNA; STING: stimulator of interferon genes; TAK1: TGF- $\beta$ activated kinase 1 ; TBK1: TRAF family member-associated NF- $\mathrm{kB}$ activator (TANK)-binding kinase 1; TIR: Toll/Interleukin-1 receptor; TIRAP: Toll/interleukin 1 receptor (TIR) domain-containing adapter protein; TLRs: Toll-like receptors; TNF $\alpha$ : tumor necrosis factor-alpha; TRAF3/6: tumor necrosis factor receptor-associated factor 3/6; TRIF: Toll/interleukin-1 receptor domain-containing adapter-inducing interferon- $\beta$; TRAM: TRIF-related adapter molecule; VACV: vaccinia virus; VARV: variola virus; vIL-18BPs: viral IL-18 
binding proteins; vIL-1 $\beta R$ : viral IL-1 $\beta$ receptor; VIPER: viral inhibitory peptide of TLR4; vPOP: viral pyrin-only proteins; vSlfn: viral Schlafen; WR: Western Reserve; ZBP1: Z-DNA binding protein 1; $\mathrm{Z} \alpha$ : Z-nucleic acid binding domain; 2-5As: $2^{\prime}-5^{\prime}$-oligoadenylates; $2^{\prime} 3^{\prime}$ cGAMP: $2^{\prime} 3^{\prime}$ cyclic guanosine monophosphate-adenosine monophosphate; $5^{\prime}$ ppp-dsRNA: $5^{\prime}$ triphosphate double-stranded RNA.

\section{References}

1. Haller, S.L.; Peng, C.; McFadden, G.; Rothenburg, S. Poxviruses and the evolution of host range and virulence. Infect. Genet. Evol. J. Mol. Epidemiol. Evol. Genet. Infect. Dis. 2014, 21, 15-40. [CrossRef]

2. Silva, N.I.O.; de Oliveira, J.S.; Kroon, E.G.; Trindade, G.D.S.; Drumond, B.P. Here, There, and Everywhere: The Wide Host Range and Geographic Distribution of Zoonotic Orthopoxviruses. Viruses 2020, 13, 43. [CrossRef]

3. Moss, B. Poxvirus DNA replication. Cold Spring Harb. Perspect. Biol. 2013, 5. [CrossRef] [PubMed]

4. McFadden, G. Poxvirus tropism. Nat. Rev. Microbiol. 2005, 3, 201-213. [CrossRef] [PubMed]

5. Durski, K.N.; McCollum, A.M.; Nakazawa, Y.; Petersen, B.W.; Reynolds, M.G.; Briand, S.; Khalakdina, A. Emergence of monkeypox in West Africa and Central Africa, 1970-2017. Relev. Epidemiol. Hebd. 2018, 93, 125-132. [CrossRef] [PubMed]

6. Tuppurainen, E.S.M.; Venter, E.H.; Shisler, J.L.; Gari, G.; Mekonnen, G.A.; Juleff, N.; Lyons, N.A.; De Clercq, K.; Upton, C.; Bowden, T.R.; et al. Review: Capripoxvirus Diseases: Current Status and Opportunities for Control. Transbound. Emerg. Dis. 2017, 64, 729-745. [CrossRef]

7. Spiesschaert, B.; McFadden, G.; Hermans, K.; Nauwynck, H.; Van De Walle, G.R. The current status and future directions of myxoma virus, a master in immune evasion. Vet. Res. 2011, 42, 76. [CrossRef]

8. Smith, G.L.; Benfield, C.T.O.; Maluquer de Motes, C.; Mazzon, M.; Ember, S.W.J.; Ferguson, B.J.; Sumner, R.P. Vaccinia virus immune evasion: Mechanisms, virulence and immunogenicity. J. Gen. Virol. 2013, 94, 2367-2392. [CrossRef] [PubMed]

9. Albarnaz, J.D.; Torres, A.A.; Smith, G.L. Modulating Vaccinia Virus Immunomodulators to Improve Immunological Memory. Viruses 2018, 10, 101. [CrossRef]

10. Staib, C.; Kisling, S.; Erfle, V.; Sutter, G. Inactivation of the viral interleukin 1beta receptor improves CD8+ T-cell memory responses elicited upon immunization with modified vaccinia virus Ankara. J. Gen. Virol. 2005, 86, 1997-2006. [CrossRef]

11. Falivene, J.; Del Médico Zajac, M.P.; Pascutti, M.F.; Rodríguez, A.M.; Maeto, C.; Perdiguero, B.; Gómez, C.E.; Esteban, M.; Calamante, G.; Gherardi, M.M. Improving the MVA vaccine potential by deleting the viral gene coding for the IL-18 binding protein. PLoS ONE 2012, 7, e32220. [CrossRef] [PubMed]

12. Smith, G.L.; Moss, B. Infectious poxvirus vectors have capacity for at least 25000 base pairs of foreign DNA. Gene 1983, 25, 21-28. [CrossRef]

13. Liu, R.; Americo, J.L.; Cotter, C.A.; Earl, P.L.; Erez, N.; Peng, C.; Moss, B. One or two injections of MVA-vectored vaccine shields hACE2 transgenic mice from SARS-CoV-2 upper and lower respiratory tract infection. Proc. Natl. Acad. Sci. USA 2021, 118. [CrossRef] [PubMed]

14. Wyatt, L.S.; Xiao, W.; Americo, J.L.; Earl, P.L.; Moss, B. Novel Nonreplicating Vaccinia Virus Vector Enhances Expression of Heterologous Genes and Suppresses Synthesis of Endogenous Viral Proteins. MBio 2017, 8. [CrossRef] [PubMed]

15. Sutter, G.; Moss, B. Nonreplicating vaccinia vector efficiently expresses recombinant genes. Proc. Natl. Acad. Sci. USA 1992, 89, 10847-10851. [CrossRef]

16. Werden, S.J.; McFadden, G. The role of cell signaling in poxvirus tropism: The case of the M-T5 host range protein of myxoma virus. Biochim. Biophys. Acta 2008, 1784, 228-237. [CrossRef]

17. Pisklakova, A.; McKenzie, B.; Zemp, F.; Lun, X.; Kenchappa, R.S.; Etame, A.B.; Rahman, M.M.; Reilly, K.; Pilon-Thomas, S.; McFadden, G.; et al. M011L-deficient oncolytic myxoma virus induces apoptosis in brain tumor-initiating cells and enhances survival in a novel immunocompetent mouse model of glioblastoma. Neuro. Oncol. 2016, 18, 1088-1098. [CrossRef] [PubMed]

18. Johnston, J.B.; Barrett, J.W.; Nazarian, S.H.; Goodwin, M.; Ricciuto, D.; Wang, G.; McFadden, G. A poxvirus-encoded pyrin domain protein interacts with ASC-1 to inhibit host inflammatory and apoptotic responses to infection. Immunity 2005, 23, 587-598. [CrossRef]

19. Urbasic, A.S.; Hynes, S.; Somrak, A.; Contakos, S.; Rahman, M.M.; Liu, J.; MacNeill, A.L. Oncolysis of canine tumor cells by myxoma virus lacking the serp2 gene. Am. J. Vet. Res. 2012, 73, 1252-1261. [CrossRef]

20. Rahman, M.M.; McFadden, G. Oncolytic Virotherapy with Myxoma Virus. J. Clin. Med. 2020, 9, 171. [CrossRef]

21. Burshtyn, D.N. NK cells and poxvirus infection. Front. Immunol. 2013, 4, 7. [CrossRef]

22. Medeiros-Silva, D.C.; Dos Santos Moreira-Silva, E.A.; de Assis Silva Gomes, J.; da Fonseca, F.G.; Correa-Oliveira, R. CD4 and CD8 T cells participate in the immune memory response against Vaccinia virus after a previous natural infection. Results Immunol. 2013, 3, 104-113. [CrossRef] [PubMed]

23. Pütz, M.M.; Midgley, C.M.; Law, M.; Smith, G.L. Quantification of antibody responses against multiple antigens of the two infectious forms of Vaccinia virus provides a benchmark for smallpox vaccination. Nat. Med. 2006, 12, 1310-1315. [CrossRef] [PubMed]

24. Zhu, J.; Martinez, J.; Huang, X.; Yang, Y. Innate immunity against vaccinia virus is mediated by TLR2 and requires TLRindependent production of IFN-beta. Blood 2007, 109, 619-625. [CrossRef]

25. Hutchens, M.; Luker, K.E.; Sottile, P.; Sonstein, J.; Lukacs, N.W.; Núñez, G.; Curtis, J.L.; Luker, G.D. TLR3 increases disease morbidity and mortality from vaccinia infection. J. Immunol. 2008, 180, 483-491. [CrossRef] 
26. Samuelsson, C.; Hausmann, J.; Lauterbach, H.; Schmidt, M.; Akira, S.; Wagner, H.; Chaplin, P.; Suter, M.; O’Keeffe, M.; Hochrein, H. Survival of lethal poxvirus infection in mice depends on TLR9, and therapeutic vaccination provides protection. J. Clin. Investig. 2008, 118, 1776-1784. [CrossRef]

27. Wolferstätter, M.; Schweneker, M.; Späth, M.; Lukassen, S.; Klingenberg, M.; Brinkmann, K.; Wielert, U.; Lauterbach, H.; Hochrein, H.; Chaplin, P.; et al. Recombinant modified vaccinia virus Ankara generating excess early double-stranded RNA transiently activates protein kinase R and triggers enhanced innate immune responses. J. Virol. 2014, 88, 14396-14411. [CrossRef] [PubMed]

28. Rice, A.D.; Turner, P.C.; Embury, J.E.; Moldawer, L.L.; Baker, H.V.; Moyer, R.W. Roles of vaccinia virus genes E3L and K3L and host genes PKR and RNase L during intratracheal infection of C57BL/6 mice. J. Virol. 2011, 85, 550-567. [CrossRef] [PubMed]

29. Delaloye, J.; Roger, T.; Steiner-Tardivel, Q.-G.; Le Roy, D.; Knaup Reymond, M.; Akira, S.; Petrilli, V.; Gomez, C.E.; Perdiguero, B.; Tschopp, J.; et al. Innate immune sensing of modified vaccinia virus Ankara (MVA) is mediated by TLR2-TLR6, MDA-5 and the NALP3 inflammasome. PLoS Pathog. 2009, 5, e1000480. [CrossRef]

30. Hornung, V.; Ablasser, A.; Charrel-Dennis, M.; Bauernfeind, F.; Horvath, G.; Caffrey, D.R.; Latz, E.; Fitzgerald, K.A. AIM2 recognizes cytosolic dsDNA and forms a caspase-1-activating inflammasome with ASC. Nature 2009, 458, 514-518. [CrossRef]

31. El-Jesr, M.; Teir, M.; Maluquer de Motes, C. Vaccinia Virus Activation and Antagonism of Cytosolic DNA Sensing. Front. Immunol. 2020, 11, 568412. [CrossRef]

32. McNab, F.; Mayer-Barber, K.; Sher, A.; Wack, A.; O'Garra, A. Type I interferons in infectious disease. Nat. Rev. Immunol. 2015, 15, 87-103. [CrossRef]

33. Gasteiger, G.; D’Osualdo, A.; Schubert, D.A.; Weber, A.; Bruscia, E.M.; Hartl, D. Cellular Innate Immunity: An Old Game with New Players. J. Innate Immun. 2017, 9, 111-125. [CrossRef] [PubMed]

34. Johnston, J.B.; McFadden, G. Poxvirus immunomodulatory strategies: Current perspectives. J. Virol. 2003, 77, 6093-6100. [CrossRef] [PubMed]

35. Roberts, W.K.; Hovanessian, A.; Brown, R.E.; Clemens, M.J.; Kerr, I.M. Interferon-mediated protein kinase and low-molecularweight inhibitor of protein synthesis. Nature 1976, 264, 477-480. [CrossRef] [PubMed]

36. Hovanessian, A.G. On the discovery of interferon-inducible, double-stranded RNA activated enzymes: The $2^{\prime}-5^{\prime}$ oligoadenylate synthetases and the protein kinase PKR. Cytokine Growth Factor Rev. 2007, 18, 351-361. [CrossRef]

37. Tuazon Kels, M.J.; Ng, E.; Al Rumaih, Z.; Pandey, P.; Ruuls, S.R.; Korner, H.; Newsome, T.P.; Chaudhri, G.; Karupiah, G. TNF deficiency dysregulates inflammatory cytokine production, leading to lung pathology and death during respiratory poxvirus infection. Proc. Natl. Acad. Sci. USA 2020, 117, 15935-15946. [CrossRef]

38. Liu, L.; Xu, Z.; Fuhlbrigge, R.C.; Peña-Cruz, V.; Lieberman, J.; Kupper, T.S. Vaccinia virus induces strong immunoregulatory cytokine production in healthy human epidermal keratinocytes: A novel strategy for immune evasion. J. Virol. 2005, 79, 7363-7370. [CrossRef] [PubMed]

39. Ivashkiv, L.B.; Donlin, L.T. Regulation of type I interferon responses. Nat. Rev. Immunol. 2014, 14, 36-49. [CrossRef]

40. Platanitis, E.; Decker, T. Regulatory Networks Involving STATs, IRFs, and NFkB in Inflammation. Front. Immunol. 2018, 9, 2542. [CrossRef]

41. Ullah, M.O.; Sweet, M.J.; Mansell, A.; Kellie, S.; Kobe, B. TRIF-dependent TLR signaling, its functions in host defense and inflammation, and its potential as a therapeutic target. J. Leukoc. Biol. 2016, 100, 27-45. [CrossRef]

42. Piras, V.; Selvarajoo, K. Beyond MyD88 and TRIF Pathways in Toll-Like Receptor Signaling. Front. Immunol. 2014, 5, 70. [CrossRef] [PubMed]

43. Thaiss, C.A.; Levy, M.; Itav, S.; Elinav, E. Integration of Innate Immune Signaling. Trends Immunol. 2016, 37, 84-101. [CrossRef]

44. Boone, R.F.; Parr, R.P.; Moss, B. Intermolecular duplexes formed from polyadenylylated vaccinia virus RNA. J. Virol. 1979, 30, 365-374. [CrossRef]

45. Colby, C.; Jurale, C.; Kates, J.R. Mechanism of synthesis of vaccinia virus double-stranded ribonucleic acid in vivo and in vitro. J. Virol. 1971, 7, 71-76. [CrossRef]

46. Willis, K.L.; Langland, J.O.; Shisler, J.L. Viral double-stranded RNAs from vaccinia virus early or intermediate gene transcripts possess PKR activating function, resulting in NF- $\mathrm{kB}$ activation, when the K1 protein is absent or mutated. J. Biol. Chem. 2011, 286, 7765-7778. [CrossRef]

47. Lebleu, B.; Sen, G.C.; Shaila, S.; Cabrer, B.; Lengyel, P. Interferon, double-stranded RNA, and protein phosphorylation. Proc. Natl. Acad. Sci. USA 1976, 73, 3107-3111. [CrossRef]

48. Hovanessian, A.G.; Brown, R.E.; Kerr, I.M. Synthesis of low molecular weight inhibitor of protein synthesis with enzyme from interferon-treated cells. Nature 1977, 268, 537-540. [CrossRef]

49. Kerr, I.M.; Brown, R.E.; Hovanessian, A.G. Nature of inhibitor of cell-free protein synthesis formed in response to interferon and double-stranded RNA. Nature 1977, 268, 540-542. [CrossRef] [PubMed]

50. Meurs, E.; Chong, K.; Galabru, J.; Thomas, N.S.B.; Kerr, I.M.; Williams, B.R.G.; Hovanessian, A.G. Molecular cloning and characterization of the human double-stranded RNA-activated protein kinase induced by interferon. Cell 1990, 62, 379-390. [CrossRef]

51. Rebouillat, D.; Hovanessian, A.G. The human $2^{\prime}, 5^{\prime}$-oligoadenylate synthetase family: Interferon-induced proteins with unique enzymatic properties. J. Interf. Cytokine Res. 1999, 19, 295-308. [CrossRef] 
52. Nanduri, S.; Carpick, B.W.; Yang, Y.; Williams, B.R.; Qin, J. Structure of the double-stranded RNA-binding domain of the protein kinase PKR reveals the molecular basis of its dsRNA-mediated activation. EMBO J. 1998, 17, 5458-5465. [CrossRef]

53. Lemaire, P.A.; Anderson, E.; Lary, J.; Cole, J.L. Mechanism of PKR Activation by dsRNA. J. Mol. Biol. 2008, 381, 351-360. [CrossRef]

54. Dey, M.; Cao, C.; Dar, A.C.; Tamura, T.; Ozato, K.; Sicheri, F.; Dever, T.E. Mechanistic link between PKR dimerization, autophosphorylation, and eIF2alpha substrate recognition. Cell 2005, 122, 901-913. [CrossRef]

55. Dever, T.E.; Kinzy, T.G.; Pavitt, G.D. Mechanism and Regulation of Protein Synthesis in Saccharomyces cerevisiae. Genetics 2016, 203, 65-107. [CrossRef]

56. Adomavicius, T.; Guaita, M.; Zhou, Y.; Jennings, M.D.; Latif, Z.; Roseman, A.M.; Pavitt, G.D. The structural basis of translational control by eIF2 phosphorylation. Nat. Commun. 2019, 10, 2136. [CrossRef]

57. Dey, M.; Mann, B.R.; Anshu, A.; Mannan, M.A. Activation of protein kinase PKR requires dimerization-induced cisphosphorylation within the activation loop. J. Biol. Chem. 2014, 289, 5747-5757. [CrossRef] [PubMed]

58. Baird, T.D.; Wek, R.C. Eukaryotic initiation factor 2 phosphorylation and translational control in metabolism. Adv. Nutr. 2012, 3, 307-321. [CrossRef]

59. Pfaller, C.K.; Li, Z.; George, C.X.; Samuel, C.E. Protein kinase PKR and RNA adenosine deaminase ADAR1: New roles for old players as modulators of the interferon response. Curr. Opin. Immunol. 2011, 23, 573-582. [CrossRef]

60. Zamanian-Daryoush, M.; Mogensen, T.H.; DiDonato, J.A.; Williams, B.R. NF-kappaB activation by double-stranded-RNAactivated protein kinase (PKR) is mediated through NF-kappaB-inducing kinase and IkappaB kinase. Mol. Cell. Biol. 2000, 20, 1278-1290. [CrossRef] [PubMed]

61. McAllister, C.S.; Taghavi, N.; Samuel, C.E. Protein kinase PKR amplification of interferon $\beta$ induction occurs through initiation factor eIF-2 $\alpha$-mediated translational control. J. Biol. Chem. 2012, 287, 36384-36392. [CrossRef] [PubMed]

62. Der, S.D.; Lau, A.S. Involvement of the double-stranded-RNA-dependent kinase PKR in interferon expression and interferonmediated antiviral activity. Proc. Natl. Acad. Sci. USA 1995, 92, 8841-8845. [CrossRef]

63. Gil, J.; Rullas, J.; García, M.A.; Alcamí, J.; Esteban, M. The catalytic activity of dsRNA-dependent protein kinase, PKR, is required for NF-kappaB activation. Oncogene 2001, 20, 385-394. [CrossRef]

64. Pham, A.M.; Santa Maria, F.G.; Lahiri, T.; Friedman, E.; Marié, I.J.; Levy, D.E. PKR Transduces MDA5-Dependent Signals for Type I IFN Induction. PLoS Pathog. 2016, 12, e1005489. [CrossRef]

65. Rojas, M.; Vasconcelos, G.; Dever, T.E. An eIF2 $\alpha$-binding motif in protein phosphatase 1 subunit GADD34 and its viral orthologs is required to promote dephosphorylation of eIF2 $\alpha$. Proc. Natl. Acad. Sci. USA 2015, 112, E3466-E3475. [CrossRef]

66. Chang, H.W.; Jacobs, B.L. Identification of a conserved motif that is necessary for binding of the vaccinia virus E3L gene products to double-stranded RNA. Virology 1993, 194, 537-547. [CrossRef]

67. Romano, P.R.; Zhang, F.; Tan, S.-L.; Garcia-Barrio, M.T.; Katze, M.G.; Dever, T.E.; Hinnebusch, A.G. Inhibition of Double-Stranded RNA-Dependent Protein Kinase PKR by Vaccinia Virus E3: Role of Complex Formation and the E3 N-Terminal Domain. Mol. Cell. Biol. 1998, 18, 7304-7316. [CrossRef]

68. Myskiw, C.; Arsenio, J.; Hammett, C.; van Bruggen, R.; Deschambault, Y.; Beausoleil, N.; Babiuk, S.; Cao, J. Comparative analysis of poxvirus orthologues of the vaccinia virus E3 protein: Modulation of protein kinase R activity, cytokine responses, and virus pathogenicity. J. Virol. 2011, 85, 12280-12291. [CrossRef]

69. Langland, J.O.; Jacobs, B.L. The role of the PKR-inhibitory genes, E3L and K3L, in determining vaccinia virus host range. Virology 2002, 299, 133-141. [CrossRef]

70. Zhang, P.; Jacobs, B.L.; Samuel, C.E. Loss of Protein Kinase PKR Expression in Human HeLa Cells Complements the Vaccinia Virus E3L Deletion Mutant Phenotype by Restoration of Viral Protein Synthesis. J. Virol. 2008, 82, 840-848. [CrossRef]

71. Rahman, M.M.; Liu, J.; Chan, W.M.; Rothenburg, S.; McFadden, G. Myxoma virus protein M029 is a dual function immunomodulator that inhibits PKR and also conscripts RHA/DHX9 to promote expanded host tropism and viral replication. PLoS Pathog. 2013, 9, e1003465. [CrossRef]

72. Park, C.; Peng, C.; Brennan, G.; Rothenburg, S. Species-specific inhibition of antiviral protein kinase R by capripoxviruses and vaccinia virus. Ann. N. Y. Acad. Sci. 2019, 1438, 18-29. [CrossRef]

73. Beattie, E.; Tartaglia, J.; Paoletti, E. Vaccinia virus-encoded eIF-2 alpha homolog abrogates the antiviral effect of interferon. Virology 1991, 183, 419-422. [CrossRef]

74. Dar, A.C.; Sicheri, F. X-ray crystal structure and functional analysis of vaccinia virus K3L reveals molecular determinants for PKR subversion and substrate recognition. Mol. Cell 2002, 10, 295-305. [CrossRef]

75. Ramelot, T.A.; Cort, J.R.; Yee, A.A.; Liu, F.; Goshe, M.B.; Edwards, A.M.; Smith, R.D.; Arrowsmith, C.H.; Dever, T.E.; Kennedy, M.A. Myxoma virus immunomodulatory protein M156R is a structural mimic of eukaryotic translation initiation factor eIF2alpha. J. Mol. Biol. 2002, 322, 943-954. [CrossRef]

76. Rothenburg, S.; Seo, E.J.; Gibbs, J.S.; Dever, T.E.; Dittmar, K. Rapid evolution of protein kinase PKR alters sensitivity to viral inhibitors. Nat. Struct. Mol. Biol. 2009, 16, 63-70. [CrossRef]

77. Peng, C.; Haller, S.L.; Rahman, M.M.; McFadden, G.; Rothenburg, S. Myxoma virus M156 is a specific inhibitor of rabbit PKR but contains a loss-of-function mutation in Australian virus isolates. Proc. Natl. Acad. Sci. USA 2016, 113, 3855-3860. [CrossRef] [PubMed] 
78. Park, C.; Peng, C.; Rahman, M.J.; Haller, S.L.; Tazi, L.; Brennan, G.; Rothenburg, S. Orthopoxvirus K3 orthologs show virus- and host-specific inhibition of the antiviral protein kinase PKR. PLoS Pathog. 2021, 17, e1009183. [CrossRef] [PubMed]

79. Cao, J.; Varga, J.; Deschambault, Y. Poxvirus encoded eIF2 $\alpha$ homolog, K3 family proteins, is a key determinant of poxvirus host species specificity. Virology 2020, 541, 101-112. [CrossRef]

80. Shors, T.; Keck, J.G.; Moss, B. Down regulation of gene expression by the vaccinia virus D10 protein. J. Virol. 1999, 73, 791-796. [CrossRef]

81. Parrish, S.; Moss, B. Characterization of a second vaccinia virus mRNA-decapping enzyme conserved in poxviruses. J. Virol. 2007, 81, 12973-12978. [CrossRef]

82. Parrish, S.; Resch, W.; Moss, B. Vaccinia virus D10 protein has mRNA decapping activity, providing a mechanism for control of host and viral gene expression. Proc. Natl. Acad. Sci. USA 2007, 104, 2139-2144. [CrossRef]

83. Liu, S.-W.; Katsafanas, G.C.; Liu, R.; Wyatt, L.S.; Moss, B. Poxvirus decapping enzymes enhance virulence by preventing the accumulation of dsRNA and the induction of innate antiviral responses. Cell Host Microbe 2015, 17, 320-331. [CrossRef]

84. Burgess, H.M.; Mohr, I. Cellular 5'-3' mRNA exonuclease Xrn1 controls double-stranded RNA accumulation and anti-viral responses. Cell Host Microbe 2015, 17, 332-344. [CrossRef] [PubMed]

85. Bratke, K.A.; McLysaght, A.; Rothenburg, S. A survey of host range genes in poxvirus genomes. Infect. Genet. Evol. J. Mol. Epidemiol. Evol. Genet. Infect. Dis. 2013, 14, 406-425. [CrossRef]

86. Chebath, J.; Benech, P.; Hovanessian, A.; Galabru, J.; Revel, M. Four different forms of interferon-induced $2^{\prime}, 5^{\prime}$-oligo(A) synthetase identified by immunoblotting in human cells. J. Biol. Chem. 1987, 262, 3852-3857. [CrossRef]

87. Silverman, R.H. Viral encounters with $2^{\prime}, 5^{\prime}$-oligoadenylate synthetase and RNase L during the interferon antiviral response. J. Virol. 2007, 81, 12720-12729. [CrossRef]

88. Li, Y.; Dong, B.; Wei, Z.; Silverman, R.H.; Weiss, S.R. Activation of RNase L in Egyptian Rousette Bat-Derived RoNi/7 Cells Is Dependent Primarily on OAS3 and Independent of MAVS Signaling. MBio 2019, 10. [CrossRef] [PubMed]

89. Li, Y.; Banerjee, S.; Wang, Y.; Goldstein, S.A.; Dong, B.; Gaughan, C.; Silverman, R.H.; Weiss, S.R. Activation of RNase L is dependent on OAS3 expression during infection with diverse human viruses. Proc. Natl. Acad. Sci. USA 2016, 113, $2241-2246$. [CrossRef]

90. Luthra, P.; Sun, D.; Silverman, R.H.; He, B. Activation of IFN- $\beta$ expression by a viral mRNA through RNase L and MDA5. Proc. Natl. Acad. Sci. USA 2011, 108, 2118-2123. [CrossRef] [PubMed]

91. Malathi, K.; Dong, B.; Gale, M.J.; Silverman, R.H. Small self-RNA generated by RNase L amplifies antiviral innate immunity. Nature 2007, 448, 816-819. [CrossRef]

92. Rong, E.; Wang, X.; Chen, H.; Yang, C.; Hu, J.; Liu, W.; Wang, Z.; Chen, X.; Zheng, H.; Pu, J.; et al. Molecular Mechanisms for the Adaptive Switching Between the OAS/RNase L and OASL/RIG-I Pathways in Birds and Mammals. Front. Immunol. 2018, 9, 1398. [CrossRef]

93. Manivannan, P.; Siddiqui, M.A.; Malathi, K. RNase L Amplifies Interferon Signaling by Inducing Protein Kinase R-Mediated Antiviral Stress Granules. J. Virol. 2020, 94. [CrossRef]

94. Díaz-Guerra, M.; Rivas, C.; Esteban, M. Inducible expression of the 2-5A synthetase/RNase L system results in inhibition of vaccinia virus replication. Virology 1997, 227, 220-228. [CrossRef]

95. Rivas, C.; Gil, J.; Mĕlková, Z.; Esteban, M.; Díaz-Guerra, M. Vaccinia virus E3L protein is an inhibitor of the interferon (i.f.n.)induced 2-5A synthetase enzyme. Virology 1998, 243, 406-414. [CrossRef]

96. Ludwig, H.; Mages, J.; Staib, C.; Lehmann, M.H.; Lang, R.; Sutter, G. Role of viral factor E3L in modified vaccinia virus ankara infection of human HeLa Cells: Regulation of the virus life cycle and identification of differentially expressed host genes. J. Virol. 2005, 79, 2584-2596. [CrossRef] [PubMed]

97. Xiang, Y.; Condit, R.C.; Vijaysri, S.; Jacobs, B.; Williams, B.R.G.; Silverman, R.H. Blockade of interferon induction and action by the E3L double-stranded RNA binding proteins of vaccinia virus. J. Virol. 2002, 76, 5251-5259. [CrossRef]

98. Liu, S.-W.; Wyatt, L.S.; Orandle, M.S.; Minai, M.; Moss, B. The D10 decapping enzyme of vaccinia virus contributes to decay of cellular and viral mRNAs and to virulence in mice. J. Virol. 2014, 88, 202-211. [CrossRef]

99. Liu, R.; Moss, B. Opposing Roles of Double-Stranded RNA Effector Pathways and Viral Defense Proteins Revealed with CRISPR-Cas9 Knockout Cell Lines and Vaccinia Virus Mutants. J. Virol. 2016, 90, 7864-7879. [CrossRef] [PubMed]

100. Andrejeva, J.; Childs, K.S.; Young, D.F.; Carlos, T.S.; Stock, N.; Goodbourn, S.; Randall, R.E. The V proteins of paramyxoviruses bind the IFN-inducible RNA helicase, mda-5, and inhibit its activation of the IFN-beta promoter. Proc. Natl. Acad. Sci. USA 2004, 101, 17264-17269. [CrossRef] [PubMed]

101. Yoneyama, M.; Kikuchi, M.; Natsukawa, T.; Shinobu, N.; Imaizumi, T.; Miyagishi, M.; Taira, K.; Akira, S.; Fujita, T. The RNA helicase RIG-I has an essential function in double-stranded RNA-induced innate antiviral responses. Nat. Immunol. 2004, 5, 730-737. [CrossRef] [PubMed]

102. Hartmann, G. Nucleic Acid Immunity. Adv. Immunol. 2017, 133, 121-169. [CrossRef] [PubMed]

103. Uhlén, M.; Fagerberg, L.; Hallström, B.M.; Lindskog, C.; Oksvold, P.; Mardinoglu, A.; Sivertsson, Å.; Kampf, C.; Sjöstedt, E.; Asplund, A.; et al. Proteomics. Tissue-based map of the human proteome. Science 2015, 347, 1260419. [CrossRef] [PubMed]

104. Luthra, P.; Ramanan, P.; Mire, C.E.; Weisend, C.; Tsuda, Y.; Yen, B.; Liu, G.; Leung, D.W.; Geisbert, T.W.; Ebihara, H.; et al. Mutual antagonism between the Ebola virus VP35 protein and the RIG-I activator PACT determines infection outcome. Cell Host Microbe 2013, 14, 74-84. [CrossRef] 
105. Liu, Y.; Olagnier, D.; Lin, R. Host and Viral Modulation of RIG-I-Mediated Antiviral Immunity. Front. Immunol. 2016, 7, 662. [CrossRef]

106. Chiu, Y.-H.; Macmillan, J.B.; Chen, Z.J. RNA polymerase III detects cytosolic DNA and induces type I interferons through the RIG-I pathway. Cell 2009, 138, 576-591. [CrossRef]

107. Wang, F.; Gao, X.; Barrett, J.W.; Shao, Q.; Bartee, E.; Mohamed, M.R.; Rahman, M.; Werden, S.; Irvine, T.; Cao, J.; et al. RIG-I mediates the co-induction of tumor necrosis factor and type I interferon elicited by myxoma virus in primary human macrophages. PLoS Pathog. 2008, 4, e1000099. [CrossRef]

108. Deng, L.; Dai, P.; Parikh, T.; Cao, H.; Bhoj, V.; Sun, Q.; Chen, Z.; Merghoub, T.; Houghton, A.; Shuman, S. Vaccinia virus subverts a mitochondrial antiviral signaling protein-dependent innate immune response in keratinocytes through its double-stranded RNA binding protein, E3. J. Virol. 2008, 82, 10735-10746. [CrossRef]

109. Brisse, M.; Ly, H. Comparative Structure and Function Analysis of the RIG-I-Like Receptors: RIG-I and MDA5. Front. Immunol. 2019, 10, 1586. [CrossRef]

110. Hornung, V.; Ellegast, J.; Kim, S.; Brzózka, K.; Jung, A.; Kato, H.; Poeck, H.; Akira, S.; Conzelmann, K.-K.; Schlee, M.; et al. 5'-Triphosphate RNA is the ligand for RIG-I. Science 2006, 314, 994-997. [CrossRef]

111. Myong, S.; Cui, S.; Cornish, P.V.; Kirchhofer, A.; Gack, M.U.; Jung, J.U.; Hopfner, K.-P.; Ha, T. Cytosolic viral sensor RIG-I is a 5'-triphosphate-dependent translocase on double-stranded RNA. Science 2009, 323, 1070-1074. [CrossRef]

112. Rehwinkel, J.; Gack, M.U. RIG-I-like receptors: Their regulation and roles in RNA sensing. Nat. Rev. Immunol. 2020, $20,537-551$. [CrossRef]

113. Kato, H.; Takeuchi, O.; Mikamo-Satoh, E.; Hirai, R.; Kawai, T.; Matsushita, K.; Hiiragi, A.; Dermody, T.S.; Fujita, T.; Akira, S. Lengthdependent recognition of double-stranded ribonucleic acids by retinoic acid-inducible gene-I and melanoma differentiationassociated gene 5. J. Exp. Med. 2008, 205, 1601-1610. [CrossRef]

114. Seth, R.B.; Sun, L.; Ea, C.-K.; Chen, Z.J. Identification and characterization of MAVS, a mitochondrial antiviral signaling protein that activates NF-kappaB and IRF 3. Cell 2005, 122, 669-682. [CrossRef] [PubMed]

115. Vazquez, C.; Horner, S.M. MAVS Coordination of Antiviral Innate Immunity. J. Virol. 2015, 89, 6974-6977. [CrossRef] [PubMed]

116. Myskiw, C.; Arsenio, J.; Booy, E.P.; Hammett, C.; Deschambault, Y.; Gibson, S.B.; Cao, J. RNA species generated in vaccinia virus infected cells activate cell type-specific MDA5 or RIG-I dependent interferon gene transcription and PKR dependent apoptosis. Virology 2011, 413, 183-193. [CrossRef]

117. Valentine, R.; Smith, G.L. Inhibition of the RNA polymerase III-mediated dsDNA-sensing pathway of innate immunity by vaccinia virus protein E3. J. Gen. Virol. 2010, 91, 2221-2229. [CrossRef]

118. Fu, Y.; Comella, N.; Tognazzi, K.; Brown, L.F.; Dvorak, H.F.; Kocher, O. Cloning of DLM-1, a novel gene that is up-regulated in activated macrophages, using RNA differential display. Gene 1999, 240, 157-163. [CrossRef]

119. Schwartz, T.; Behlke, J.; Lowenhaupt, K.; Heinemann, U.; Rich, A. Structure of the DLM-1-Z-DNA complex reveals a conserved family of Z-DNA-binding proteins. Nat. Struct. Biol. 2001, 8, 761-765. [CrossRef]

120. Rothenburg, S.; Schwartz, T.; Koch-Nolte, F.; Haag, F. Complex regulation of the human gene for the Z-DNA binding protein DLM-1. Nucleic Acids Res. 2002, 30, 993-1000. [CrossRef]

121. Deigendesch, N.; Koch-Nolte, F.; Rothenburg, S. ZBP1 subcellular localization and association with stress granules is controlled by its Z-DNA binding domains. Nucleic Acids Res. 2006, 34, 5007-5020. [CrossRef]

122. Feng, S.; Li, H.; Zhao, J.; Pervushin, K.; Lowenhaupt, K.; Schwartz, T.U.; Dröge, P. Alternate rRNA secondary structures as regulators of translation. Nat. Struct. Mol. Biol. 2011, 18, 169-176. [CrossRef]

123. Takaoka, A.; Wang, Z.; Choi, M.K.; Yanai, H.; Negishi, H.; Ban, T.; Lu, Y.; Miyagishi, M.; Kodama, T.; Honda, K.; et al. DAI (DLM-1/ZBP1) is a cytosolic DNA sensor and an activator of innate immune response. Nature 2007, 448, 501-505. [CrossRef]

124. Wang, Z.; Choi, M.K.; Ban, T.; Yanai, H.; Negishi, H.; Lu, Y.; Tamura, T.; Takaoka, A.; Nishikura, K.; Taniguchi, T. Regulation of innate immune responses by DAI (DLM-1/ZBP1) and other DNA-sensing molecules. Proc. Natl. Acad. Sci. USA 2008, 105, 5477-5482. [CrossRef]

125. DeFilippis, V.R.; Alvarado, D.; Sali, T.; Rothenburg, S.; Früh, K. Human cytomegalovirus induces the interferon response via the DNA sensor ZBP1. J. Virol. 2010, 84, 585-598. [CrossRef]

126. Koehler, H.; Cotsmire, S.; Langland, J.; Kibler, K.V.; Kalman, D.; Upton, J.W.; Mocarski, E.S.; Jacobs, B.L. Inhibition of DAIdependent necroptosis by the Z-DNA binding domain of the vaccinia virus innate immune evasion protein, E3. Proc. Natl. Acad. Sci. USA 2017, 114, 11506-11511. [CrossRef]

127. Rebsamen, M.; Heinz, L.X.; Meylan, E.; Michallet, M.-C.; Schroder, K.; Hofmann, K.; Vazquez, J.; Benedict, C.A.; Tschopp, J. DAI/ZBP1 recruits RIP1 and RIP3 through RIP homotypic interaction motifs to activate NF-kappaB. EMBO Rep. 2009, 10, 916-922. [CrossRef] [PubMed]

128. Upton, J.W.; Kaiser, W.J.; Mocarski, E.S. DAI/ZBP1/DLM-1 complexes with RIP3 to mediate virus-induced programmed necrosis that is targeted by murine cytomegalovirus vIRA. Cell Host Microbe 2012, 11, 290-297. [CrossRef]

129. Kaiser, W.J.; Upton, J.W.; Mocarski, E.S. Receptor-interacting protein homotypic interaction motif-dependent control of NF-kappa B activation via the DNA-dependent activator of IFN regulatory factors. J. Immunol. 2008, 181, 6427-6434. [CrossRef] [PubMed]

130. Koehler, H.S.; Jacobs, B.L. Subversion of Programed Cell Death by Poxviruses. Curr. Top. Microbiol. Immunol. 2021. [CrossRef]

131. Brandt, T.A.; Jacobs, B.L. Both carboxy- and amino-terminal domains of the vaccinia virus interferon resistance gene, E3L, are required for pathogenesis in a mouse model. J. Virol. 2001, 75, 850-856. [CrossRef] 
132. Kim, Y.-G.; Muralinath, M.; Brandt, T.; Pearcy, M.; Hauns, K.; Lowenhaupt, K.; Jacobs, B.L.; Rich, A. A role for Z-DNA binding in vaccinia virus pathogenesis. Proc. Natl. Acad. Sci. USA 2003, 100, 6974-6979. [CrossRef] [PubMed]

133. Stetson, D.B.; Medzhitov, R. Recognition of cytosolic DNA activates an IRF3-dependent innate immune response. Immunity 2006, 24, 93-103. [CrossRef]

134. Ishii, K.J.; Coban, C.; Kato, H.; Takahashi, K.; Torii, Y.; Takeshita, F.; Ludwig, H.; Sutter, G.; Suzuki, K.; Hemmi, H.; et al. A Toll-like receptor-independent antiviral response induced by double-stranded B-form DNA. Nat. Immunol. 2006, 7, 40-48. [CrossRef]

135. Dempsey, A.; Bowie, A.G. Innate immune recognition of DNA: A recent history. Virology 2015, 479-480, 146-152. [CrossRef] [PubMed]

136. Sun, L.; Wu, J.; Du, F.; Chen, X.; Chen, Z.J. Cyclic GMP-AMP synthase is a cytosolic DNA sensor that activates the type I interferon pathway. Science 2013, 339, 786-791. [CrossRef]

137. Gao, P.; Ascano, M.; Wu, Y.; Barchet, W.; Gaffney, B.L.; Zillinger, T.; Serganov, A.A.; Liu, Y.; Jones, R.A.; Hartmann, G.; et al. Cyclic $\left[\mathrm{G}\left(2^{\prime}, 5^{\prime}\right) \mathrm{pA}\left(3^{\prime}, 5^{\prime}\right) \mathrm{p}\right]$ is the metazoan second messenger produced by DNA-activated cyclic GMP-AMP synthase. Cell 2013, 153, 1094-1107. [CrossRef]

138. Wu, J.; Sun, L.; Chen, X.; Du, F.; Shi, H.; Chen, C.; Chen, Z.J. Cyclic GMP-AMP is an endogenous second messenger in innate immune signaling by cytosolic DNA. Science 2013, 339, 826-830. [CrossRef] [PubMed]

139. Abe, T.; Barber, G.N. Cytosolic-DNA-mediated, STING-dependent proinflammatory gene induction necessitates canonical NF- $\kappa \mathrm{B}$ activation through TBK1. J. Virol. 2014, 88, 5328-5341. [CrossRef] [PubMed]

140. Tanaka, Y.; Chen, Z.J. STING specifies IRF3 phosphorylation by TBK1 in the cytosolic DNA signaling pathway. Sci. Signal. 2012, 5, ra20. [CrossRef] [PubMed]

141. Yum, S.; Li, M.; Fang, Y.; Chen, Z.J. TBK1 recruitment to STING activates both IRF3 and NF-kB that mediate immune defense against tumors and viral infections. Proc. Natl. Acad. Sci. USA 2021, 118. [CrossRef]

142. Xu, R.-H.; Wong, E.B.; Rubio, D.; Roscoe, F.; Ma, X.; Nair, S.; Remakus, S.; Schwendener, R.; John, S.; Shlomchik, M.; et al. Sequential Activation of Two Pathogen-Sensing Pathways Required for Type I Interferon Expression and Resistance to an Acute DNA Virus Infection. Immunity 2015, 43, 1148-1159. [CrossRef]

143. Cheng, W.-Y.; He, X.-B.; Jia, H.-J.; Chen, G.-H.; Jin, Q.-W.; Long, Z.-L.; Jing, Z.-Z. The cGas-Sting Signaling Pathway Is Required for the Innate Immune Response Against Ectromelia Virus. Front. Immunol. 2018, 9, 1297. [CrossRef]

144. Li, X.-D.; Wu, J.; Gao, D.; Wang, H.; Sun, L.; Chen, Z.J. Pivotal roles of cGAS-cGAMP signaling in antiviral defense and immune adjuvant effects. Science 2013, 341, 1390-1394. [CrossRef]

145. Dai, P.; Wang, W.; Cao, H.; Avogadri, F.; Dai, L.; Drexler, I.; Joyce, J.A.; Li, X.-D.; Chen, Z.; Merghoub, T.; et al. Modified vaccinia virus Ankara triggers type I IFN production in murine conventional dendritic cells via a cGAS/STING-mediated cytosolic DNA-sensing pathway. PLoS Pathog. 2014, 10, e1003989. [CrossRef]

146. Georgana, I.; Sumner, R.P.; Towers, G.J.; Maluquer de Motes, C. Virulent Poxviruses Inhibit DNA Sensing by Preventing STING Activation. J. Virol. 2018, 92. [CrossRef]

147. Meade, N.; King, M.; Munger, J.; Walsh, D. mTOR Dysregulation by Vaccinia Virus F17 Controls Multiple Processes with Varying Roles in Infection. J. Virol. 2019, 93. [CrossRef]

148. Meade, N.; Furey, C.; Li, H.; Verma, R.; Chai, Q.; Rollins, M.G.; DiGiuseppe, S.; Naghavi, M.H.; Walsh, D. Poxviruses Evade Cytosolic Sensing through Disruption of an mTORC1-mTORC2 Regulatory Circuit. Cell 2018, 174, 1143-1157.e17. [CrossRef]

149. Eaglesham, J.B.; Pan, Y.; Kupper, T.S.; Kranzusch, P.J. Viral and metazoan poxins are cGAMP-specific nucleases that restrict cGAS-STING signalling. Nature 2019, 566, 259-263. [CrossRef] [PubMed]

150. Hernáez, B.; Alonso, G.; Georgana, I.; El-Jesr, M.; Martín, R.; Shair, K.H.Y.; Fischer, C.; Sauer, S.; Maluquer de Motes, C.; Alcamí, A. Viral cGAMP nuclease reveals the essential role of DNA sensing in protection against acute lethal virus infection. Sci. Adv. 2020, 6 . [CrossRef]

151. Unterholzner, L.; Sumner, R.P.; Baran, M.; Ren, H.; Mansur, D.S.; Bourke, N.M.; Randow, F.; Smith, G.L.; Bowie, A.G. Vaccinia virus protein $\mathrm{C} 6$ is a virulence factor that binds TBK-1 adaptor proteins and inhibits activation of IRF3 and IRF7. PLoS Pathog. 2011, 7, e1002247. [CrossRef] [PubMed]

152. Ferguson, B.J.; Benfield, C.T.O.; Ren, H.; Lee, V.H.; Frazer, G.L.; Strnadova, P.; Sumner, R.P.; Smith, G.L. Vaccinia virus protein N2 is a nuclear IRF3 inhibitor that promotes virulence. J. Gen. Virol. 2013, 94, 2070-2081. [CrossRef] [PubMed]

153. Ramsay, E.P.; Abascal-Palacios, G.; Daiß, J.L.; King, H.; Gouge, J.; Pilsl, M.; Beuron, F.; Morris, E.; Gunkel, P.; Engel, C.; et al. Structure of human RNA polymerase III. Nat. Commun. 2020, 11, 6409. [CrossRef]

154. Ablasser, A.; Bauernfeind, F.; Hartmann, G.; Latz, E.; Fitzgerald, K.A.; Hornung, V. RIG-I-dependent sensing of poly(dA:dT) through the induction of an RNA polymerase III-transcribed RNA intermediate. Nat. Immunol. 2009, 10, 1065-1072. [CrossRef]

155. Almine, J.F.; O’Hare, C.A.J.; Dunphy, G.; Haga, I.R.; Naik, R.J.; Atrih, A.; Connolly, D.J.; Taylor, J.; Kelsall, I.R.; Bowie, A.G.; et al. IFI16 and cGAS cooperate in the activation of STING during DNA sensing in human keratinocytes. Nat. Commun. 2017, 8, 14392. [CrossRef]

156. Stratmann, S.A.; Morrone, S.R.; van Oijen, A.M.; Sohn, J. The innate immune sensor IFI16 recognizes foreign DNA in the nucleus by scanning along the duplex. Elife 2015, 4, e11721. [CrossRef] [PubMed]

157. Monroe, K.M.; Yang, Z.; Johnson, J.R.; Geng, X.; Doitsh, G.; Krogan, N.J.; Greene, W.C. IFI16 DNA sensor is required for death of lymphoid CD4 T cells abortively infected with HIV. Science 2014, 343, 428-432. [CrossRef] 
158. Orzalli, M.H.; DeLuca, N.A.; Knipe, D.M. Nuclear IFI16 induction of IRF-3 signaling during herpesviral infection and degradation of IFI16 by the viral ICP0 protein. Proc. Natl. Acad. Sci. USA 2012, 109, E3008-E3017. [CrossRef]

159. Unterholzner, L.; Keating, S.E.; Baran, M.; Horan, K.A.; Jensen, S.B.; Sharma, S.; Sirois, C.M.; Jin, T.; Latz, E.; Xiao, T.S.; et al. IFI16 is an innate immune sensor for intracellular DNA. Nat. Immunol. 2010, 11, 997-1004. [CrossRef]

160. Walker, J.R.; Corpina, R.A.; Goldberg, J. Structure of the Ku heterodimer bound to DNA and its implications for double-strand break repair. Nature 2001, 412, 607-614. [CrossRef]

161. Zhang, X.; Brann, T.W.; Zhou, M.; Yang, J.; Oguariri, R.M.; Lidie, K.B.; Imamichi, H.; Huang, D.-W.; Lempicki, R.A.; Baseler, M.W.; et al. Cutting edge: Ku70 is a novel cytosolic DNA sensor that induces type III rather than type I IFN. J. Immunol. 2011, 186, 4541-4545. [CrossRef] [PubMed]

162. Sui, H.; Zhou, M.; Imamichi, H.; Jiao, X.; Sherman, B.T.; Lane, H.C.; Imamichi, T. STING is an essential mediator of the Ku70-mediated production of IFN- $\lambda 1$ in response to exogenous DNA. Sci. Signal. 2017, 10. [CrossRef]

163. Ferguson, B.J.; Mansur, D.S.; Peters, N.E.; Ren, H.; Smith, G.L. DNA-PK is a DNA sensor for IRF-3-dependent innate immunity. Elife 2012, 1, e00047. [CrossRef] [PubMed]

164. Peters, N.E.; Ferguson, B.J.; Mazzon, M.; Fahy, A.S.; Krysztofinska, E.; Arribas-Bosacoma, R.; Pearl, L.H.; Ren, H.; Smith, G.L. A mechanism for the inhibition of DNA-PK-mediated DNA sensing by a virus. PLoS Pathog. 2013, 9, e1003649. [CrossRef] [PubMed]

165. Scutts, S.R.; Ember, S.W.; Ren, H.; Ye, C.; Lovejoy, C.A.; Mazzon, M.; Veyer, D.L.; Sumner, R.P.; Smith, G.L. DNA-PK Is Targeted by Multiple Vaccinia Virus Proteins to Inhibit DNA Sensing. Cell Rep. 2018, 25, 1953-1965.e4. [CrossRef] [PubMed]

166. Fahy, A.S.; Clark, R.H.; Glyde, E.F.; Smith, G.L. Vaccinia virus protein C16 acts intracellularly to modulate the host response and promote virulence. J. Gen. Virol. 2008, 89, 2377-2387. [CrossRef] [PubMed]

167. Zhang, Z.; Yuan, B.; Bao, M.; Lu, N.; Kim, T.; Liu, Y.-J. The helicase DDX41 senses intracellular DNA mediated by the adaptor STING in dendritic cells. Nat. Immunol. 2011, 12, 959-965. [CrossRef]

168. Parvatiyar, K.; Zhang, Z.; Teles, R.M.; Ouyang, S.; Jiang, Y.; Iyer, S.S.; Zaver, S.A.; Schenk, M.; Zeng, S.; Zhong, W.; et al. The helicase DDX41 recognizes the bacterial secondary messengers cyclic di-GMP and cyclic di-AMP to activate a type I interferon immune response. Nat. Immunol. 2012, 13, 1155-1161. [CrossRef]

169. Omura, H.; Oikawa, D.; Nakane, T.; Kato, M.; Ishii, R.; Ishitani, R.; Tokunaga, F.; Nureki, O. Structural and Functional Analysis of DDX41: A bispecific immune receptor for DNA and cyclic dinucleotide. Sci. Rep. 2016, 6, 34756. [CrossRef]

170. Rock, F.L.; Hardiman, G.; Timans, J.C.; Kastelein, R.A.; Bazan, J.F. A family of human receptors structurally related to Drosophila Toll. Proc. Natl. Acad. Sci. USA 1998, 95, 588-593. [CrossRef]

171. Lemaitre, B.; Nicolas, E.; Michaut, L.; Reichhart, J.M.; Hoffmann, J.A. The dorsoventral regulatory gene cassette spätzle/Toll/cactus controls the potent antifungal response in Drosophila adults. Cell 1996, 86, 973-983. [CrossRef]

172. Michel, T.; Reichhart, J.M.; Hoffmann, J.A.; Royet, J. Drosophila Toll is activated by Gram-positive bacteria through a circulating peptidoglycan recognition protein. Nature 2001, 414, 756-759. [CrossRef] [PubMed]

173. Lemaitre, B.; Hoffmann, J. The host defense of Drosophila melanogaster. Annu. Rev. Immunol. 2007, 25, 697-743. [CrossRef] [PubMed]

174. Liu, G.; Zhang, H.; Zhao, C.; Zhang, H. Evolutionary History of the Toll-Like Receptor Gene Family across Vertebrates. Genome Biol. Evol. 2020, 12, 3615-3634. [CrossRef] [PubMed]

175. Botos, I.; Segal, D.M.; Davies, D.R. The structural biology of Toll-like receptors. Structure 2011, 19, 447-459. [CrossRef] [PubMed]

176. Chaturvedi, A.; Pierce, S.K. How location governs toll-like receptor signaling. Traffic 2009, 10, 621-628. [CrossRef] [PubMed]

177. Kawai, T.; Sato, S.; Ishii, K.J.; Coban, C.; Hemmi, H.; Yamamoto, M.; Terai, K.; Matsuda, M.; Inoue, J.; Uematsu, S.; et al. Interferon-alpha induction through Toll-like receptors involves a direct interaction of IRF7 with MyD88 and TRAF6. Nat. Immunol. 2004, 5, 1061-1068. [CrossRef]

178. De Nardo, D.; Balka, K.R.; Cardona Gloria, Y.; Rao, V.R.; Latz, E.; Masters, S.L. Interleukin-1 receptor-associated kinase 4 (IRAK4) plays a dual role in myddosome formation and Toll-like receptor signaling. J. Biol. Chem. 2018, 293, 15195-15207. [CrossRef]

179. Zhang, J.; Macartney, T.; Peggie, M.; Cohen, P. Interleukin-1 and TRAF6-dependent activation of TAK1 in the absence of TAB2 and TAB3. Biochem. J. 2017, 474, 2235-2248. [CrossRef] [PubMed]

180. Kanarek, N.; London, N.; Schueler-Furman, O.; Ben-Neriah, Y. Ubiquitination and degradation of the inhibitors of NF-kappaB. Cold Spring Harb. Perspect. Biol. 2010, 2, a000166. [CrossRef]

181. Liu, T.; Zhang, L.; Joo, D.; Sun, S.-C. NF-kB signaling in inflammation. Signal Transduct. Target. Ther. 2017, 2, 17023. [CrossRef]

182. Shin, C.H.; Choi, D.-S. Essential Roles for the Non-Canonical IkB Kinases in Linking Inflammation to Cancer, Obesity, and Diabetes. Cells 2019, 8, 178. [CrossRef]

183. Alexopoulou, L.; Holt, A.C.; Medzhitov, R.; Flavell, R.A. Recognition of double-stranded RNA and activation of NF-kappaB by Toll-like receptor 3. Nature 2001, 413, 732-738. [CrossRef] [PubMed]

184. Liu, L.; Botos, I.; Wang, Y.; Leonard, J.N.; Shiloach, J.; Segal, D.M.; Davies, D.R. Structural basis of toll-like receptor 3 signaling with double-stranded RNA. Science 2008, 320, 379-381. [CrossRef] [PubMed]

185. Son, K.-N.; Liang, Z.; Lipton, H.L. Double-Stranded RNA Is Detected by Immunofluorescence Analysis in RNA and DNA Virus Infections, Including Those by Negative-Stranded RNA Viruses. J. Virol. 2015, 89, 9383-9392. [CrossRef] [PubMed]

186. Yamamoto, M.; Sato, S.; Hemmi, H.; Hoshino, K.; Kaisho, T.; Sanjo, H.; Takeuchi, O.; Sugiyama, M.; Okabe, M.; Takeda, K.; et al. Role of adaptor TRIF in the MyD88-independent toll-like receptor signaling pathway. Science 2003, 301, 640-643. [CrossRef] 
187. Israely, T.; Melamed, S.; Achdout, H.; Erez, N.; Politi, B.; Waner, T.; Lustig, S.; Paran, N. TLR3 and TLR9 agonists improve postexposure vaccination efficacy of live smallpox vaccines. PLoS ONE 2014, 9, e110545. [CrossRef] [PubMed]

188. Harte, M.T.; Haga, I.R.; Maloney, G.; Gray, P.; Reading, P.C.; Bartlett, N.W.; Smith, G.L.; Bowie, A.; O’Neill, L.A.J. The poxvirus protein A52R targets Toll-like receptor signaling complexes to suppress host defense. J. Exp. Med. 2003, 197, 343-351. [CrossRef] [PubMed]

189. Stack, J.; Haga, I.R.; Schröder, M.; Bartlett, N.W.; Maloney, G.; Reading, P.C.; Fitzgerald, K.A.; Smith, G.L.; Bowie, A.G. Vaccinia virus protein A46R targets multiple Toll-like-interleukin-1 receptor adaptors and contributes to virulence. J. Exp. Med. 2005, 201, 1007-1018. [CrossRef]

190. DiPerna, G.; Stack, J.; Bowie, A.G.; Boyd, A.; Kotwal, G.; Zhang, Z.; Arvikar, S.; Latz, E.; Fitzgerald, K.A.; Marshall, W.L. Poxvirus protein N1L targets the I-kappaB kinase complex, inhibits signaling to NF-kappaB by the tumor necrosis factor superfamily of receptors, and inhibits NF-kappaB and IRF3 signaling by toll-like receptors. J. Biol. Chem. 2004, 279, 36570-36578. [CrossRef] [PubMed]

191. Chen, R.A.-J.; Ryzhakov, G.; Cooray, S.; Randow, F.; Smith, G.L. Inhibition of IkappaB kinase by vaccinia virus virulence factor B14. PLoS Pathog. 2008, 4, e22. [CrossRef] [PubMed]

192. Graham, S.C.; Bahar, M.W.; Cooray, S.; Chen, R.A.-J.; Whalen, D.M.; Abrescia, N.G.A.; Alderton, D.; Owens, R.J.; Stuart, D.I.; Smith, G.L.; et al. Vaccinia virus proteins A52 and B14 Share a Bcl-2-like fold but have evolved to inhibit NF-kappaB rather than apoptosis. PLoS Pathog. 2008, 4, e1000128. [CrossRef]

193. Schröder, M.; Baran, M.; Bowie, A.G. Viral targeting of DEAD box protein 3 reveals its role in TBK1/IKKepsilon-mediated IRF activation. EMBO J. 2008, 27, 2147-2157. [CrossRef]

194. Hornung, V.; Rothenfusser, S.; Britsch, S.; Krug, A.; Jahrsdörfer, B.; Giese, T.; Endres, S.; Hartmann, G. Quantitative expression of toll-like receptor 1-10 mRNA in cellular subsets of human peripheral blood mononuclear cells and sensitivity to CpG oligodeoxynucleotides. J. Immunol. 2002, 168, 4531-4537. [CrossRef] [PubMed]

195. Ishii, N.; Funami, K.; Tatematsu, M.; Seya, T.; Matsumoto, M. Endosomal localization of TLR8 confers distinctive proteolytic processing on human myeloid cells. J. Immunol. 2014, 193, 5118-5128. [CrossRef]

196. Ostendorf, T.; Zillinger, T.; Andryka, K.; Schlee-Guimaraes, T.M.; Schmitz, S.; Marx, S.; Bayrak, K.; Linke, R.; Salgert, S.; Wegner, J.; et al. Immune Sensing of Synthetic, Bacterial, and Protozoan RNA by Toll-like Receptor 8 Requires Coordinated Processing by RNase T2 and RNase 2. Immunity 2020, 52, 591-605.e6. [CrossRef]

197. Greulich, W.; Wagner, M.; Gaidt, M.M.; Stafford, C.; Cheng, Y.; Linder, A.; Carell, T.; Hornung, V. TLR8 Is a Sensor of RNase T2 Degradation Products. Cell 2019, 179, 1264-1275.e13. [CrossRef] [PubMed]

198. Martinez, J.; Huang, X.; Yang, Y. Toll-like receptor 8-mediated activation of murine plasmacytoid dendritic cells by vaccinia viral DNA. Proc. Natl. Acad. Sci. USA 2010, 107, 6442-6447. [CrossRef]

199. Dempsey, A.; Keating, S.E.; Carty, M.; Bowie, A.G. Poxviral protein E3-altered cytokine production reveals that DExD/H-box helicase 9 controls Toll-like receptor-stimulated immune responses. J. Biol. Chem. 2018, 293, 14989-15001. [CrossRef] [PubMed]

200. Krieg, A.M. Toll-like receptor 9 (TLR9) agonists in the treatment of cancer. Oncogene 2008, 27, 161-167. [CrossRef]

201. Hemmi, H.; Takeuchi, O.; Kawai, T.; Kaisho, T.; Sato, S.; Sanjo, H.; Matsumoto, M.; Hoshino, K.; Wagner, H.; Takeda, K.; et al. A Toll-like receptor recognizes bacterial DNA. Nature 2000, 408, 740-745. [CrossRef] [PubMed]

202. Fukui, R.; Yamamoto, C.; Matsumoto, F.; Onji, M.; Shibata, T.; Murakami, Y.; Kanno, A.; Hayashi, T.; Tanimura, N.; Yoshida, N.; et al. Cleavage of Toll-Like Receptor 9 Ectodomain Is Required for In Vivo Responses to Single Strand DNA. Front. Immunol. 2018, 9, 1491. [CrossRef]

203. Park, B.; Brinkmann, M.M.; Spooner, E.; Lee, C.C.; Kim, Y.-M.; Ploegh, H.L. Proteolytic cleavage in an endolysosomal compartment is required for activation of Toll-like receptor 9. Nat. Immunol. 2008, 9, 1407-1414. [CrossRef]

204. Uyangaa, E.; Choi, J.Y.; Patil, A.M.; Hossain, F.M.A.; Park, S.O.; Kim, B.; Kim, K.; Eo, S.K. Dual TLR2/9 Recognition of Herpes Simplex Virus Infection Is Required for Recruitment and Activation of Monocytes and NK Cells and Restriction of Viral Dissemination to the Central Nervous System. Front. Immunol. 2018, 9, 905. [CrossRef] [PubMed]

205. Lousberg, E.L.; Diener, K.R.; Fraser, C.K.; Phipps, S.; Foster, P.S.; Chen, W.; Uematsu, S.; Akira, S.; Robertson, S.A.; Brown, M.P.; et al. Antigen-specific T-cell responses to a recombinant fowlpox virus are dependent on MyD88 and interleukin-18 and independent of Toll-like receptor 7 (TLR7)- and TLR9-mediated innate immune recognition. J. Virol. 2011, 85, 3385-3396. [CrossRef] [PubMed]

206. Dai, P.; Cao, H.; Merghoub, T.; Avogadri, F.; Wang, W.; Parikh, T.; Fang, C.-M.; Pitha, P.M.; Fitzgerald, K.A.; Rahman, M.M.; et al Myxoma virus induces type I interferon production in murine plasmacytoid dendritic cells via a TLR9/MyD88-, IRF5/IRF7-, and IFNAR-dependent pathway. J. Virol. 2011, 85, 10814-10825. [CrossRef]

207. Medzhitov, R.; Preston-Hurlburt, P.; Janeway, C.A.J. A human homologue of the Drosophila Toll protein signals activation of adaptive immunity. Nature 1997, 388, 394-397. [CrossRef]

208. Flo, T.H.; Ryan, L.; Latz, E.; Takeuchi, O.; Monks, B.G.; Lien, E.; Halaas, Ø.; Akira, S.; Skjåk-Braek, G.; Golenbock, D.T.; et al. Involvement of toll-like receptor (TLR) 2 and TLR4 in cell activation by mannuronic acid polymers. J. Biol. Chem. 2002, 277, 35489-35495. [CrossRef]

209. Yang, S.; Sugawara, S.; Monodane, T.; Nishijima, M.; Adachi, Y.; Akashi, S.; Miyake, K.; Hase, S.; Takada, H. Micrococcus luteus teichuronic acids activate human and murine monocytic cells in a CD14- and toll-like receptor 4-dependent manner. Infect. Immun. 2001, 69, 2025-2030. [CrossRef] 
210. Lai, C.-Y.; Strange, D.P.; Wong, T.A.S.; Lehrer, A.T.; Verma, S. Ebola Virus Glycoprotein Induces an Innate Immune Response In vivo via TLR4. Front. Microbiol. 2017, 8, 1571. [CrossRef]

211. Georgel, P.; Jiang, Z.; Kunz, S.; Janssen, E.; Mols, J.; Hoebe, K.; Bahram, S.; Oldstone, M.B.A.; Beutler, B. Vesicular stomatitis virus glycoprotein G activates a specific antiviral Toll-like receptor 4-dependent pathway. Virology 2007, 362, 304-313. [CrossRef]

212. Kurt-Jones, E.A.; Popova, L.; Kwinn, L.; Haynes, L.M.; Jones, L.P.; Tripp, R.A.; Walsh, E.E.; Freeman, M.W.; Golenbock, D.T.; Anderson, L.J.; et al. Pattern recognition receptors TLR4 and CD14 mediate response to respiratory syncytial virus. Nat. Immunol. 2000, 1, 398-401. [CrossRef] [PubMed]

213. Huang, B.; Sikorski, R.; Kirn, D.H.; Thorne, S.H. Synergistic anti-tumor effects between oncolytic vaccinia virus and paclitaxel are mediated by the IFN response and HMGB1. Gene Ther. 2011, 18, 164-172. [CrossRef]

214. Matsumiya, M.; Stylianou, E.; Griffiths, K.; Lang, Z.; Meyer, J.; Harris, S.A.; Rowland, R.; Minassian, A.M.; Pathan, A.A.; Fletcher, H.; et al. Roles for Treg expansion and HMGB1 signaling through the TLR1-2-6 axis in determining the magnitude of the antigen-specific immune response to MVA85A. PLoS ONE 2013, 8, e67922. [CrossRef]

215. Yang, H.; Wang, H.; Ju, Z.; Ragab, A.A.; Lundbäck, P.; Long, W.; Valdes-Ferrer, S.I.; He, M.; Pribis, J.P.; Li, J.; et al. MD-2 is required for disulfide HMGB1-dependent TLR4 signaling. J. Exp. Med. 2015, 212, 5-14. [CrossRef]

216. Hutchens, M.A.; Luker, K.E.; Sonstein, J.; Núñez, G.; Curtis, J.L.; Luker, G.D. Protective effect of Toll-like receptor 4 in pulmonary vaccinia infection. PLoS Pathog. 2008, 4, e1000153. [CrossRef]

217. Kawasaki, T.; Kawai, T. Toll-like receptor signaling pathways. Front. Immunol. 2014, 5, 461. [CrossRef] [PubMed]

218. Lysakova-Devine, T.; Keogh, B.; Harrington, B.; Nagpal, K.; Halle, A.; Golenbock, D.T.; Monie, T.; Bowie, A.G. Viral inhibitory peptide of TLR4, a peptide derived from vaccinia protein A46, specifically inhibits TLR4 by directly targeting MyD88 adaptor-like and TRIF-related adaptor molecule. J. Immunol. 2010, 185, 4261-4271. [CrossRef]

219. Fedosyuk, S.; Bezerra, G.A.; Radakovics, K.; Smith, T.K.; Sammito, M.; Bobik, N.; Round, A.; Ten Eyck, L.F.; Djinović-Carugo, K.; Usón, I.; et al. Vaccinia Virus Immunomodulator A46: A Lipid and Protein-Binding Scaffold for Sequestering Host TIR-Domain Proteins. PLoS Pathog. 2016, 12, e1006079. [CrossRef] [PubMed]

220. Stack, J.; Bowie, A.G. Poxviral protein A46 antagonizes Toll-like receptor 4 signaling by targeting BB loop motifs in Toll-IL-1 receptor adaptor proteins to disrupt receptor:adaptor interactions. J. Biol. Chem. 2012, 287, 22672-22682. [CrossRef]

221. Kim, Y.; Lee, H.; Heo, L.; Seok, C.; Choe, J. Structure of vaccinia virus A46, an inhibitor of TLR4 signaling pathway, shows the conformation of VIPER motif. Protein Sci. 2014, 23, 906-914. [CrossRef]

222. Azar, D.F.; Haas, M.; Fedosyuk, S.; Rahaman, M.H.; Hedger, A.; Kobe, B.; Skern, T. Vaccinia Virus Immunomodulator A46: Destructive Interactions with MAL and MyD88 Shown by Negative-Stain Electron Microscopy. Structure 2020, 28, 1271-1287.e5. [CrossRef] [PubMed]

223. Bowie, A.; Kiss-Toth, E.; Symons, J.A.; Smith, G.L.; Dower, S.K.; O'Neill, L.A. A46R and A52R from vaccinia virus are antagonists of host IL-1 and toll-like receptor signaling. Proc. Natl. Acad. Sci. USA 2000, 97, 10162-10167. [CrossRef]

224. Jin, M.S.; Kim, S.E.; Heo, J.Y.; Lee, M.E.; Kim, H.M.; Paik, S.-G.; Lee, H.; Lee, J.-O. Crystal structure of the TLR1-TLR2 heterodimer induced by binding of a tri-acylated lipopeptide. Cell 2007, 130, 1071-1082. [CrossRef]

225. Kang, J.Y.; Nan, X.; Jin, M.S.; Youn, S.-J.; Ryu, Y.H.; Mah, S.; Han, S.H.; Lee, H.; Paik, S.-G.; Lee, J.-O. Recognition of lipopeptide patterns by Toll-like receptor 2-Toll-like receptor 6 heterodimer. Immunity 2009, 31, 873-884. [CrossRef]

226. Hanzelmann, D.; Joo, H.-S.; Franz-Wachtel, M.; Hertlein, T.; Stevanovic, S.; Macek, B.; Wolz, C.; Götz, F.; Otto, M.; Kretschmer, D.; et al. Toll-like receptor 2 activation depends on lipopeptide shedding by bacterial surfactants. Nat. Commun. 2016, 7, 12304. [CrossRef] [PubMed]

227. Fuchs, K.; Cardona Gloria, Y.; Wolz, O.-O.; Herster, F.; Sharma, L.; Dillen, C.A.; Täumer, C.; Dickhöfer, S.; Bittner, Z.; Dang, T.-M.; et al. The fungal ligand chitin directly binds TLR2 and triggers inflammation dependent on oligomer size. EMBO Rep. 2018, 19. [CrossRef]

228. Boehme, K.W.; Guerrero, M.; Compton, T. Human cytomegalovirus envelope glycoproteins B and H are necessary for TLR2 activation in permissive cells. J. Immunol. 2006, 177, 7094-7102. [CrossRef] [PubMed]

229. Dolganiuc, A.; Oak, S.; Kodys, K.; Golenbock, D.T.; Finberg, R.W.; Kurt-Jones, E.; Szabo, G. Hepatitis C core and nonstructural 3 proteins trigger toll-like receptor 2-mediated pathways and inflammatory activation. Gastroenterology 2004, 127, 1513-1524. [CrossRef]

230. Henrick, B.M.; Yao, X.-D.; Rosenthal, K.L. HIV-1 Structural Proteins Serve as PAMPs for TLR2 Heterodimers Significantly Increasing Infection and Innate Immune Activation. Front. Immunol. 2015, 6, 426. [CrossRef]

231. Kokkola, R.; Andersson, A.; Mullins, G.; Ostberg, T.; Treutiger, C.-J.; Arnold, B.; Nawroth, P.; Andersson, U.; Harris, R.A.; Harris, H.E. RAGE is the major receptor for the proinflammatory activity of HMGB1 in rodent macrophages. Scand. J. Immunol. 2005, 61, 1-9. [CrossRef]

232. Yu, M.; Wang, H.; Ding, A.; Golenbock, D.T.; Latz, E.; Czura, C.J.; Fenton, M.J.; Tracey, K.J.; Yang, H. HMGB1 signals through toll-like receptor (TLR) 4 and TLR2. Shock 2006, 26, 174-179. [CrossRef]

233. O'Gorman, W.E.; Sampath, P.; Simonds, E.F.; Sikorski, R.; O’Malley, M.; Krutzik, P.O.; Chen, H.; Panchanathan, V.; Chaudhri, G.; Karupiah, G.; et al. Alternate mechanisms of initial pattern recognition drive differential immune responses to related poxviruses. Cell Host Microbe 2010, 8, 174-185. [CrossRef]

234. Martinez, J.; Huang, X.; Yang, Y. Direct TLR2 signaling is critical for NK cell activation and function in response to vaccinia viral infection. PLoS Pathog. 2010, 6, e1000811. [CrossRef] [PubMed] 
235. González, J.M.; Esteban, M. A poxvirus Bcl-2-like gene family involved in regulation of host immune response: Sequence similarity and evolutionary history. Virol. J. 2010, 7, 59. [CrossRef] [PubMed]

236. Maluquer de Motes, C.; Cooray, S.; Ren, H.; Almeida, G.M.F.; McGourty, K.; Bahar, M.W.; Stuart, D.I.; Grimes, J.M.; Graham, S.C.; Smith, G.L. Inhibition of apoptosis and NF- $\mathrm{kB}$ activation by vaccinia protein N1 occur via distinct binding surfaces and make different contributions to virulence. PLoS Pathog. 2011, 7, e1002430. [CrossRef]

237. Stack, J.; Doyle, S.L.; Connolly, D.J.; Reinert, L.S.; O'Keeffe, K.M.; McLoughlin, R.M.; Paludan, S.R.; Bowie, A.G. TRAM is required for TLR2 endosomal signaling to type I IFN induction. J. Immunol. 2014, 193, 6090-6102. [CrossRef] [PubMed]

238. Shrivastava, G.; León-Juárez, M.; García-Cordero, J.; Meza-Sánchez, D.E.; Cedillo-Barrón, L. Inflammasomes and its importance in viral infections. Immunol. Res. 2016, 64, 1101-1117. [CrossRef]

239. Hayward, J.A.; Mathur, A.; Ngo, C.; Man, S.M. Cytosolic Recognition of Microbes and Pathogens: Inflammasomes in Action. Microbiol. Mol. Biol. Rev. 2018, 82. [CrossRef] [PubMed]

240. Man, S.M.; Karki, R.; Kanneganti, T.-D. Molecular mechanisms and functions of pyroptosis, inflammatory caspases and inflammasomes in infectious diseases. Immunol. Rev. 2017, 277, 61-75. [CrossRef]

241. Platnich, J.M.; Muruve, D.A. NOD-like receptors and inflammasomes: A review of their canonical and non-canonical signaling pathways. Arch. Biochem. Biophys. 2019, 670,4-14. [CrossRef] [PubMed]

242. Sharma, M.; de Alba, E. Structure, Activation and Regulation of NLRP3 and AIM2 Inflammasomes. Int. J. Mol. Sci. 2021, $22,872$. [CrossRef] [PubMed]

243. Nambayan, R.J.T.; Sandin, S.I.; Quint, D.A.; Satyadi, D.M.; de Alba, E. The inflammasome adapter ASC assembles into filaments with integral participation of its two Death Domains, PYD and CARD. J. Biol. Chem. 2019, 294, 439-452. [CrossRef]

244. Shi, J.; Zhao, Y.; Wang, K.; Shi, X.; Wang, Y.; Huang, H.; Zhuang, Y.; Cai, T.; Wang, F.; Shao, F. Cleavage of GSDMD by inflammatory caspases determines pyroptotic cell death. Nature 2015, 526, 660-665. [CrossRef]

245. Rahman, M.M.; McFadden, G. Myxoma virus lacking the pyrin-like protein M013 is sensed in human myeloid cells by both NLRP3 and multiple Toll-like receptors, which independently activate the inflammasome and NF- $\kappa \mathrm{B}$ innate response pathways. J. Virol. 2011, 85, 12505-12517. [CrossRef]

246. Zheng, D.; Liwinski, T.; Elinav, E. Inflammasome activation and regulation: Toward a better understanding of complex mechanisms. Cell Discov. 2020, 6, 36. [CrossRef]

247. Bauernfeind, F.G.; Horvath, G.; Stutz, A.; Alnemri, E.S.; MacDonald, K.; Speert, D.; Fernandes-Alnemri, T.; Wu, J.; Monks, B.G.; Fitzgerald, K.A.; et al. Cutting edge: NF-kappaB activating pattern recognition and cytokine receptors license NLRP3 inflammasome activation by regulating NLRP3 expression. J. Immunol. 2009, 183, 787-791. [CrossRef]

248. Boaru, S.G.; Borkham-Kamphorst, E.; Van de Leur, E.; Lehnen, E.; Liedtke, C.; Weiskirchen, R. NLRP3 inflammasome expression is driven by NF-kB in cultured hepatocytes. Biochem. Biophys. Res. Commun. 2015, 458, 700-706. [CrossRef] [PubMed]

249. Kelley, N.; Jeltema, D.; Duan, Y.; He, Y. The NLRP3 Inflammasome: An Overview of Mechanisms of Activation and Regulation. Int. J. Mol. Sci. 2019, 20, 3328. [CrossRef]

250. Strittmatter, G.E.; Sand, J.; Sauter, M.; Seyffert, M.; Steigerwald, R.; Fraefel, C.; Smola, S.; French, L.E.; Beer, H.-D. IFN- $\gamma$ Primes Keratinocytes for HSV-1-Induced Inflammasome Activation. J. Investig. Dermatol. 2016, 136, 610-620. [CrossRef]

251. Dorfleutner, A.; Talbott, S.J.; Bryan, N.B.; Funya, K.N.; Rellick, S.L.; Reed, J.C.; Shi, X.; Rojanasakul, Y.; Flynn, D.C.; Stehlik, C. A Shope Fibroma virus PYRIN-only protein modulates the host immune response. Virus Genes 2007, 35, 685-694. [CrossRef] [PubMed]

252. Rahman, M.M.; Mohamed, M.R.; Kim, M.; Smallwood, S.; McFadden, G. Co-regulation of NF-kappaB and inflammasomemediated inflammatory responses by myxoma virus pyrin domain-containing protein M013. PLoS Pathog. 2009, 5, e1000635. [CrossRef]

253. Garg, R.R.; Jackson, C.B.; Rahman, M.M.; Khan, A.R.; Lewin, A.S.; McFadden, G. Myxoma virus M013 protein antagonizes NF-кB and inflammasome pathways via distinct structural motifs. J. Biol. Chem. 2019, 294, 8480-8489. [CrossRef] [PubMed]

254. Smith, G.L.; Howard, S.T.; Chan, Y.S. Vaccinia virus encodes a family of genes with homology to serine proteinase inhibitors. J. Gen. Virol. 1989, 70 Pt 9, 2333-2343. [CrossRef]

255. Ray, C.A.; Black, R.A.; Kronheim, S.R.; Greenstreet, T.A.; Sleath, P.R.; Salvesen, G.S.; Pickup, D.J. Viral inhibition of inflammation: Cowpox virus encodes an inhibitor of the interleukin-1 beta converting enzyme. Cell 1992, 69, 597-604. [CrossRef]

256. Bloomer, D.T.; Kitevska-Ilioski, T.; Pantaki-Eimany, D.; Ji, Y.; Miles, M.A.; Heras, B.; Hawkins, C.J. CrmA orthologs from diverse poxviruses potently inhibit caspases- 1 and -8 , yet cleavage site mutagenesis frequently produces caspase-1-specific variants. Biochem. J. 2019, 476, 1335-1357. [CrossRef]

257. Alcamí, A.; Smith, G.L. A soluble receptor for interleukin-1 beta encoded by vaccinia virus: A novel mechanism of virus modulation of the host response to infection. Cell 1992, 71, 153-167. [CrossRef]

258. Smith, V.P.; Alcami, A. Expression of secreted cytokine and chemokine inhibitors by ectromelia virus. J. Virol. 2000, 74, 8460-8471. [CrossRef]

259. Xiang, Y.; Moss, B. IL-18 binding and inhibition of interferon gamma induction by human poxvirus-encoded proteins. Proc. Natl. Acad. Sci. USA 1999, 96, 11537-11542. [CrossRef]

260. Smith, V.P.; Bryant, N.A.; Alcamí, A. Ectromelia, vaccinia and cowpox viruses encode secreted interleukin-18-binding proteins. J. Gen. Virol. 2000, 81, 1223-1230. [CrossRef] 
261. Meng, X.; Leman, M.; Xiang, Y. Variola virus IL-18 binding protein interacts with three human IL-18 residues that are part of a binding site for human IL-18 receptor alpha subunit. Virology 2007, 358, 211-220. [CrossRef] [PubMed]

262. Schattgen, S.A.; Fitzgerald, K.A. The PYHIN protein family as mediators of host defenses. Immunol. Rev. 2011, 243, 109-118. [CrossRef]

263. Lu, A.; Li, Y.; Yin, Q.; Ruan, J.; Yu, X.; Egelman, E.; Wu, H. Plasticity in PYD assembly revealed by cryo-EM structure of the PYD filament of AIM2. Cell Discov. 2015, 1, 15013. [CrossRef]

264. Wang, B.; Yin, Q. AIM2 inflammasome activation and regulation: A structural perspective. J. Struct. Biol. 2017, $200,279-282$. [CrossRef] [PubMed]

265. Bürckstümmer, T.; Baumann, C.; Blüml, S.; Dixit, E.; Dürnberger, G.; Jahn, H.; Planyavsky, M.; Bilban, M.; Colinge, J.; Bennett, K.L.; et al. An orthogonal proteomic-genomic screen identifies AIM2 as a cytoplasmic DNA sensor for the inflammasome. Nat. Immunol. 2009, 10, 266-272. [CrossRef] [PubMed]

266. Fernandes-Alnemri, T.; Yu, J.-W.; Datta, P.; Wu, J.; Alnemri, E.S. AIM2 activates the inflammasome and cell death in response to cytoplasmic DNA. Nature 2009, 458, 509-513. [CrossRef]

267. Roberts, T.L.; Idris, A.; Dunn, J.A.; Kelly, G.M.; Burnton, C.M.; Hodgson, S.; Hardy, L.L.; Garceau, V.; Sweet, M.J.; Ross, I.L.; et al. HIN-200 proteins regulate caspase activation in response to foreign cytoplasmic DNA. Science 2009, 323, 1057-1060. [CrossRef]

268. Rathinam, V.A.K.; Jiang, Z.; Waggoner, S.N.; Sharma, S.; Cole, L.E.; Waggoner, L.; Vanaja, S.K.; Monks, B.G.; Ganesan, S.; Latz, E.; et al. The AIM2 inflammasome is essential for host defense against cytosolic bacteria and DNA viruses. Nat. Immunol. 2010, 11, 395-402. [CrossRef]

269. Fernandes-Alnemri, T.; Yu, J.-W.; Juliana, C.; Solorzano, L.; Kang, S.; Wu, J.; Datta, P.; McCormick, M.; Huang, L.; McDermott, E.; et al. The AIM2 inflammasome is critical for innate immunity to Francisella tularensis. Nat. Immunol. 2010, 11, 385-393. [CrossRef]

270. Sauer, J.-D.; Witte, C.E.; Zemansky, J.; Hanson, B.; Lauer, P.; Portnoy, D.A. Listeria monocytogenes triggers AIM2-mediated pyroptosis upon infrequent bacteriolysis in the macrophage cytosol. Cell Host Microbe 2010, 7, 412-419. [CrossRef]

271. Saiga, H.; Kitada, S.; Shimada, Y.; Kamiyama, N.; Okuyama, M.; Makino, M.; Yamamoto, M.; Takeda, K. Critical role of AIM2 in Mycobacterium tuberculosis infection. Int. Immunol. 2012, 24, 637-644. [CrossRef] [PubMed]

272. Rothenburg, S.; Brennan, G. Species-Specific Host-Virus Interactions: Implications for Viral Host Range and Virulence. Trends Microbiol. 2020, 28, 46-56. [CrossRef] [PubMed] 